\title{
Prepartum Nutrition Alters Fatty Acid Composition in Plasma, Adipose Tissue, and Liver Lipids of Periparturient Dairy Cows ${ }^{1}$
}

\author{
G. N. Douglas, ${ }^{\star 2}$ J. Rehage,$\dagger$ A. D. Beaulieu, ${ }^{\star 3}$ A. O. Bahaa, ${ }^{*}$ and J. K. Drackley ${ }^{\star 4}$ \\ *Department of Animal Sciences, University of Illinois, Urbana 61801 \\ †Clinic for Cattle, School of Veterinary Medicine, Hannover, Germany
}

\begin{abstract}
The fatty acyl profile of phospholipids (PL) determines the fluidity of cell membranes and affects cell function. The degree to which long-chain fatty acid (LCFA) composition of PL and triacylglycerols (TG) in liver and total lipids in adipose tissue can be altered by prepartum nutrition in peripartal dairy cows is unclear. Multiparous Holsteins $(\mathrm{n}=25)$ were assigned to 1 of 4 prepartal diets: 1) CA, the control diet fed to meet $120 \%$ of energy requirements; 2 ) CR, a control diet fed to meet $80 \%$ of requirements; 3 ) S, a diet supplemented with mostly saturated free fatty acids (47\% 16:0, 36\% 18:0, $14 \%$ cis-18:1) and fed to meet $120 \%$ of requirements; or 4) U, a diet similar to S except that cows were abomasally infused with soybean oil so that the diet plus infused fat would meet $120 \%$ of requirements. Diets were fed for $40 \mathrm{~d}$ prepartum; all cows received a lactation diet postpartum. Groups CR and U had lower prepartum intakes of dry matter and net energy, but glucose concentrations in plasma were similar among treatments. Cows fed S, U, or CR had greater nonesterified fatty acids in plasma prepartum, but cows fed $\mathrm{U}$ had decreased $\beta$-hydroxybutyrate postpartum. Postpartal concentrations of total lipids and glycogen in liver tissue were similar among treatments. Cows in group U had a greater percentage of 18:2 but less 16:0, 18:0, and 20:4 in plasma total lipids than cows fed S. Treatment U increased 18:2 and 18:3 and decreased 18:1 in subcutaneous adipose tissue at $1 \mathrm{~d}$ postpartum. Across diets, percentages of 16:0 and trans-18:1 were increased, and 18:0, 20:3, and 20:5 were decreased, in hepatic PL at d 1 postpartum. Significant treatment $\times$ time interactions indicated that treatment $\mathrm{U}$ increased 18:2 in hepatic

Received April 14, 2006.

Accepted February 16, 2007.

${ }^{1}$ Supported by federal and state funds appropriated to the Illinois Agricultural Experiment Station. J. Rehage was supported by the Deutsche Forschungsgemeinschaft (reference \#DFG 819/5-1).

${ }^{2}$ Current address: CPO 1862, Berea College, Berea, KY 40404.

${ }^{3}$ Current address: Prairie Swine Centre, PO Box 21057, Saskatoon, Saskatchewan, Canada S7H 5N9.

${ }^{4}$ Corresponding author: drackley@uiuc.edu
\end{abstract}

PL at the expense of $18: 1,20: 3,20: 4,22: 6$, and $24: 0$ on d 1 postpartum, but changes were normalized by d 65 postpartum. The unsaturation index of hepatic PL was lower at $d 1$ than at $d-45$ or 65 , which implies that hepatic membrane fluidity decreased around parturition. The unsaturation index at $d 1$ was greater for cows fed S than those fed CA or U. Percentages of 16:0, 18:1, and 22:0 were increased, and 18:0, 20:3, 20:4, 20:5, 24:0, and 26:0 were decreased, in hepatic TG at $d$. Prepartal feed restriction modestly affected tissue LCFA profiles. The LCFA profile of adipose tissue, liver PL, and liver TG can be altered by dietary LCFA supply prepartum; changes in liver are normalized by $65 \mathrm{~d}$ postpartum.

Key words: periparturient cows, fatty acid composition, liver metabolism, supplemental fat

\section{INTRODUCTION}

The profile and amount of long-chain fatty acids (LCFA) and their metabolites in tissues have been shown to modify metabolism in animals. In particular, the polyunsaturated fatty acid (PUFA) composition of membrane phospholipids (PL) and stored triacylglycerols (TG) has been implicated in a wide variety of disease states in laboratory animals and humans (Zamaria, 2004; Hulbert et al., 2005). The PUFA may affect metabolism via interactions with nuclear transcription factors (Jump, 2002), by altering production of prostaglandins and leukotrienes (Calder, 2005), and by affecting cell signaling and signal transduction mechanisms (Ashes et al., 1995; Switzer et al., 2004). Changes in PUFA availability affect membrane fluidity and function (Hulbert et al., 2005), which can alter the activity of membrane-associated proteins such as sodium-potassium ATPase (Hulbert et al., 2005) and carnitine palmitoyltransferase-1 (Kolodziej and Zammit, 1990b); the latter enzyme regulates import of LCFA into mitochondria for oxidation in dairy cows (Dann and Drackley, 2005).

The PUFA status of ruminants is notoriously precarious because ruminal biohydrogenation of dietary PUFA limits the postruminal supply for absorption (Noble, 1984). Consequently, it has been proposed that increas- 
ing the intestinal supply of PUFA during critical periods, such as the transition from pregnancy to lactation in dairy cows, might be beneficial to health and productivity (Noble, 1984). Lipids in ruminant milk and tissues can be enriched in contents of n-3 and n- 6 PUFA to a degree similar to that in nonruminant tissues if sources of these PUFA are protected from ruminal biohydrogenation (Cook et al., 1972; Bilby et al., 2006). Increasing the PUFA supply might affect hepatic metabolism associated with peripartal TG accumulation. By inducing enzymes associated with LCFA catabolism (Jump, 2002), PUFA decreased TG accumulation in rodent liver (Yoshida et al., 1999). Different PUFA vary in their effect on hepatic metabolism in ruminants. In vitro studies with bovine hepatocytes have presented conflicting evidence on the effects of changing the availability of various PUFA on LCFA metabolism and gluconeogenesis (Andersen et al., 2001; Mashek et al., 2002; Mashek and Grummer, 2003a). In feed-deprived nonlactating cows, intravenous administration of emulsions containing linseed oil (rich in 18:3) resulted in lower hepatic TG concentration than did infusions of fish oil (high in 20:5 and 22:6) or tallow (Mashek et al., 2005).

The LCFA profile of liver changes in periparturient cows as a result of the mobilization and hepatic uptake of LCFA from adipose tissue (Rukkwamsuk et al., 2000). Hepatic LCFA profiles differ between cows with fatty liver and those without (Rukkwamsuk et al., 1999, 2000 ). We have shown previously that moderate feed restriction of cows (limiting cows to $80 \%$ of their calculated net energy requirements) during the dry period results in greater DMI and decreased TG in liver postpartum compared with overfeeding during the dry period (Douglas et al., 2006). Restricted cows also had greater activity of carnitine palmitoyltransferase- 1 in hepatic mitochondria (Dann and Drackley, 2005). Alterations in hepatic LCFA might have contributed to these beneficial outcomes, but the effects of moderate feed restriction on hepatic LCFA profiles have not been determined.

Regardless of whether altering hepatic concentrations of specific PUFA may beneficially affect metabolism in periparturient cows, a key unanswered question is whether tissue pools of PUFA can be enriched by increasing the postruminal supply of PUFA during the relatively short time of a dry period or prepartum transition period and, if so, how long the enrichment would persist after parturition. Therefore, the objectives of this study were to determine the effects of prepartum nutrition (supplemental saturated or unsaturated LCFA; adequate or restricted DMI) on LCFA composition of total lipids in plasma and adipose tissue, and in liver PL and TG at parturition. We also measured
Table 1. Ingredient composition of diets fed to dry and lactating cows

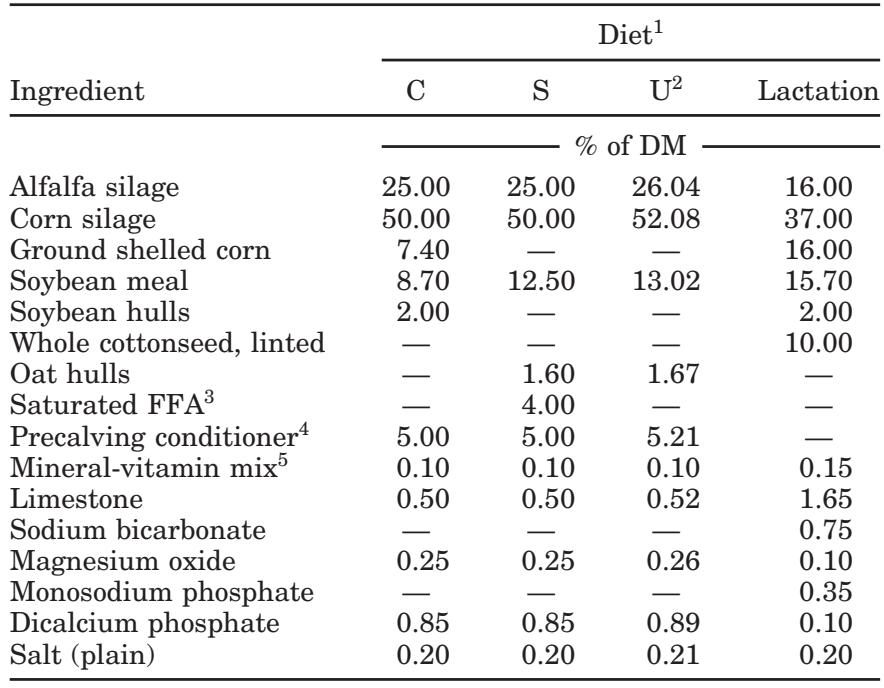

${ }^{1}$ Control diet (C) containing no supplemental fat fed to meet $120 \%$ (CA) or $80 \%$ (CR) of the $\mathrm{NE}_{\mathrm{L}}$ requirement for dry cows (NRC, 1989); $\mathrm{S}=$ diet containing mostly saturated fatty acids and fed to meet $120 \%$ of the $\mathrm{NE}_{\mathrm{L}}$ requirement; $\mathrm{U}=$ diet supplemented with soybean oil that was infused directly into the abomasum and fed to meet $120 \%$ of the $\mathrm{NE}_{\mathrm{L}}$ requirement.

${ }^{2}$ Soybean oil (4\% of dietary DM, based on previous day's DMI) was infused directly into the abomasum via a catheter placed through the rumen cannula.

${ }^{3}$ Energy Booster 100 (Milk Specialties, Dundee, IL).

${ }^{4}$ Contained a maximum content of $5 \%$ crude fiber, minimum contents of $10 \% \mathrm{CP}$ and $1 \%$ ether extract, $2.5 \% \mathrm{Mg}, 3.2 \% \mathrm{~S}, 0.43 \% \mathrm{~K}$, $16.5 \% \mathrm{Cl}, 0.0007 \% \mathrm{Se}, 110 \mathrm{IU} / \mathrm{g}$ of vitamin $\mathrm{A}, 44 \mathrm{IU} / \mathrm{g}$ of vitamin $\mathrm{D}$, $1.32 \mathrm{IU} / \mathrm{g}$ of vitamin $\mathrm{E}$, and $13.2 \mathrm{mg} / \mathrm{g}$ niacin.

${ }^{5}$ Contained $5.0 \% \mathrm{Mg}, 7.5 \% \mathrm{~K}, 10.0 \% \mathrm{~S}, 0.5 \% \mathrm{Na}, 3.0 \% \mathrm{Cl}, 3.0 \% \mathrm{Zn}$, $3.0 \% \mathrm{Mn}, 2.0 \% \mathrm{Fe}, 0.5 \% \mathrm{Cu}, 0.015 \% \mathrm{Se}, 0.004 \% \mathrm{Co}, 0.025 \% \mathrm{I}, 1,000$ $\mathrm{IU} / \mathrm{g}$ of vitamin A, $300 \mathrm{IU} / \mathrm{g}$ of vitamin D, and $3.5 \mathrm{IU} / \mathrm{g}$ of vitamin $\mathrm{E}$.

changes in hepatic LCFA composition into early lactation to determine whether dry period effects persisted.

\section{MATERIALS AND METHODS}

\section{Cows, Diets, and Experimental Design}

All procedures were conducted under protocols approved by the University of Illinois Laboratory Animal Care Advisory Committee. Thirty Holstein cows whose previous lactation was discontinued $60 \mathrm{~d}$ before their expected parturition date were assigned randomly to receive 1 of 4 diets from $-40 \mathrm{~d}$ relative to expected parturition until actual calving. Cows calved from June 12, 1998, through September 14, 1998. Cows were housed in tie stalls throughout the early dry period and during lactation, and were allowed to exercise daily in an outside lot from $0600 \mathrm{~h}$ to $0930 \mathrm{~h}$. Two weeks before expected parturition, cows were moved to maternity box stalls until parturition and continued to receive the same diet and exercise regimen. After parturition, all cows were offered a single lactation diet (Table 1) that 
Table 2. Fatty acid composition of fat sources used to supplement diets during the dry period

\begin{tabular}{lcc}
\hline & $\begin{array}{c}\text { Saturated } \\
\text { fatty acids }\end{array}$ & \\
& & Soybean oil \\
\cline { 2 - 3 } Component & 1.9 & $\mathrm{~g} / 100 \mathrm{~g}$ of fatty acids \\
\cline { 2 - 3 } $14: 0$ & $\mathrm{ND}^{2}$ & 0.6 \\
$16: 1$ & 46.6 & $\mathrm{ND}$ \\
$16: 1$ & $\mathrm{ND}$ & 11.5 \\
$18: 0$ & 36.2 & $\mathrm{ND}$ \\
$18: 1$ & 13.6 & 4.0 \\
$18: 2$ & 0.9 & 25.1 \\
$18: 3$ & $\mathrm{ND}$ & 52.0 \\
Other & 0.8 & 6.2 \\
\hline
\end{tabular}

${ }^{1}$ Energy Booster 100 (Milk Specialties Co., Dundee, IL).

${ }^{2}$ Not detected.

was fed as a TMR. Postpartum measurements were made for $70 \mathrm{~d}$ after calving. Diets were mixed once daily and fed twice daily at approximately 1000 and $1700 \mathrm{~h}$.

Diets (Table 1) were based on corn silage and alfalfa silage and were fed as TMR throughout the dry period. Dry period treatments consisted of 1 ) a control diet that was fed to meet $120 \%$ of the $\mathrm{NE}_{\mathrm{L}}$ requirement (NRC, 1989) for dry cows (CA), 2) the same control diet fed to meet $80 \%$ of the $\mathrm{NE}_{\mathrm{L}}$ requirement $\left.(\mathbf{C R}), 3\right)$ a diet $(\mathbf{S})$ supplemented with 4\% (DM basis) mostly saturated free LCFA (Energy Booster 100; Milk Specialties Co., Dundee, IL), and 4) a diet similar to S except that, rather than inclusion of fat in the diet, soybean oil (at a rate of $4 \%$ of total DMI, based on the previous day's DMI) was infused directly into the abomasum to avoid biohydrogenation in the rumen (U). The LCFA composition of the fat sources is reported in Table 2. The control $\operatorname{diet}(\mathrm{CA})$ was designed to promote normal LCFA composition of tissues in healthy cows during the periparturient period. Treatment CR was designed to determine effects of modest prepartal mobilization of body fat, whereas treatments S and U compared effects of enriching absorbable supplies of either mostly saturated or mostly unsaturated LCFA. Diets CA, S, and U were offered in amounts to provide $120 \%$ of the $\mathrm{NE}_{\mathrm{L}}$ requirement for dry cows (NRC, 1989) if cows consumed all the feed offered. Dry cows were limit-fed to $120 \%$ of their $\mathrm{NE}_{\mathrm{L}}$ requirements in an attempt to remove variability in $\mathrm{DM}$ and $\mathrm{NE}_{\mathrm{L}}$ intakes that might be affected by supplementing fat in the dry period diet. Amounts of feed offered to control energy intake relative to NRC (1989) requirements were based on each cow's BW at the beginning of the experiment and the calculated $\mathrm{NE}_{\mathrm{L}}$ density of the diet. The amount of fat included was higher than what might be recommended practically but was chosen to maximize effects on tissue LCFA profiles for proof of principle. A premix containing anionic salts (from fermentation by-products) was in- cluded in all dry period diets at approximately $5 \%$ of the DM (Table 1).

Cows allotted to treatment U were fitted surgically with ruminal cannulas at least $40 \mathrm{~d}$ before the initiation of the dry period treatments. At approximately $-45 \mathrm{~d}$ relative to expected parturition, vinyl tubing (Tygon, $0.635 \mathrm{~cm}$ i.d., $0.952 \mathrm{~cm}$ o.d.; Norton Performance Plastics Corporation, Akron, $\mathrm{OH}$ ) approximately $1.5 \mathrm{~m}$ in length was attached to a perforated $60-\mathrm{mL}$ polypropylene bottle that was passed through the rumen cannula to the abomasum (Litherland et al., 2005). The apparatus was held in position by a circular rubber flange attached to the infusion tubing near the neck of the bottle. The opposite end of the infusion tubing was passed through a hole in the rumen cannula and was anchored to leave approximately $15 \mathrm{~cm}$ outside the rumen for ease of infusion. Soybean oil was infused in pulse doses (Litherland et al., 2005), followed by a complete flushing of the infusion line with water at 0700 , 1300 , and $2000 \mathrm{~h}$ daily during the treatment period. The amount infused daily was determined by each cow's DMI for the previous day and averaged $330 \pm 18 \mathrm{~g} / \mathrm{d}$. Position of the perforated bottle within the abomasum and integrity of the infusion line were confirmed twice weekly during the infusion period. No rumen-cannulated cows were available to assign to treatments CA, CR, or S. Negative effects of rumen cannulation or abomasal infusion have not been detected in previous experiments (e.g., Drackley et al., 1992b; Christensen et al., 1994; Litherland et al., 2005).

Dry matter intakes were measured daily and BW and BCS were measured weekly throughout the experiment. The BCS (scale of $1=$ thin to $5=$ obese; Wildman et al., 1982) were assigned independently by 3 individuals. Health records were maintained for all cows, and calf birth weights were recorded.

\section{Sampling and Analysis of Feed and Milk}

The diet components were sampled weekly and dried at $55^{\circ} \mathrm{C}$ for determination of $\mathrm{DM}$ so that ration components could be adjusted, if necessary, to maintain dietary DM ratios as formulated. Samples of TMR components and the TMR were obtained weekly and composited monthly. Composite samples were analyzed for contents of DM, CP (method 984; AOAC, 1995), ADF and NDF (Van Soest et al., 1991), and minerals (Ca, $\mathrm{P}, \mathrm{Mg}$, and K) by Dairy One Laboratory (Ithaca, NY). Minerals were analyzed by inductively coupled plasma radial spectrometry after samples were ashed $\left(500^{\circ} \mathrm{C}\right.$ for 2 to $4 \mathrm{~h}$ ), acidified with $3 \mathrm{~mL}$ of $6 \mathrm{~N} \mathrm{HCl}$, evaporated to dryness on a hot plate at 100 to $120^{\circ} \mathrm{C}$, and extracted with acid solution $\left(1.5 \mathrm{NHNO}_{3}+0.5 \mathrm{~N} \mathrm{HCl}\right)$. The $\mathrm{NE}_{\mathrm{L}}$ of the dietary components was calculated for diet formu- 
lation using equations from the NRC (1989), and diets were evaluated for $\mathrm{NE}_{\mathrm{L}}$ according to $\mathrm{NRC}$ (2001) equations. Ether extract was measured using diethyl ether (AOAC, 1995).

Milk weights were recorded daily and samples were obtained once weekly from consecutive a.m. and p.m. milkings. Samples were composited in proportion to milk production at each sampling and were preserved with 2-bromo-2-nitropropane-1,3-diol. Composite samples were analyzed for contents of fat and total protein by infrared analysis (AOAC, 1995) by a commercial laboratory (Dairy Lab Services, Dubuque, IA).

\section{Sampling and Analysis of Blood, Liver, and Adipose Tissue}

During the dry period, blood was sampled once weekly from 40 to $14 \mathrm{~d}$ before the expected parturition date and twice weekly from $14 \mathrm{~d}$ before expected parturition through d 14 postpartum. After d 14 postpartum, blood was sampled once weekly until $70 \mathrm{~d}$ postpartum. Blood was sampled from the coccygeal vein or artery beginning at approximately $0900 \mathrm{~h}$ and all sampling was completed before the morning feeding $(1000 \mathrm{~h})$.

Blood samples were collected in evacuated test tubes (Vacutainer; Becton Dickinson Vacutainer Systems USA, Rutherford, NJ) that contained sodium heparin or potassium EDTA. Plasma obtained via centrifugation from tubes containing sodium heparin was frozen at $-20^{\circ} \mathrm{C}$ until later analysis for concentrations of NEFA, BHBA, glucose, and cholesterol using a Hitachi 911 autoanalyzer (Roche Diagnostics, Inc., Indianapolis, IN) as described elsewhere (Douglas et al., 2004, 2006). Plasma obtained from tubes containing potassium EDTA was frozen at $-20^{\circ} \mathrm{C}$ until analyzed for LCFA composition.

Puncture biopsy was performed under local anesthesia to obtain approximately 3 to $5 \mathrm{~g}$ of liver tissue (Drackley et al., 1991; Douglas et al., 2004) at $-45 \mathrm{~d}$ relative to expected parturition and at 1,21, and $65 \mathrm{~d}$ after calving. Tissue was frozen immediately in liquid $\mathrm{N}_{2}$ until analysis for contents of total lipid (Drackley et al., 1991), glycogen (Lo et al., 1970), and LCFA composition. Approximately 2 to $3 \mathrm{~g}$ of subcutaneous adipose tissue were excised from the tail head region under local anesthesia at $-45 \mathrm{~d}$ relative to expected parturition and at $\mathrm{d} 1$ after calving. Aliquots of adipose tissue were frozen immediately in liquid $\mathrm{N}_{2}$ and stored at $-80^{\circ} \mathrm{C}$ for determination of LCFA composition.

Total lipids were extracted from plasma, adipose tissue, and liver tissue by using a hexane and isopropanol (3:2) mixture as described by Hara and Radin (1978). Lipids isolated from liver tissue were further separated into PL and TG fractions by solid-phase extraction
(Bateman and Jenkins, 1997) using Sep-Pak Vac Cartridges containing amino-propyl $\left(\mathrm{NH}_{2}\right)$ sorbent (Waters Corporation, Milford, MA). Methyl esters of LCFA were prepared by the procedure of Sukhija and Palmquist (1988) and were separated by gas chromatography on an SP-2340 fused-silica capillary column $(0.32 \mathrm{~mm} \times$ $30 \mathrm{~m}$; Supelco, Bellefonte, PA) in a Shimadzu GC-17A version 3 gas chromatograph (Shimadzu Corp., Kyoto, Japan). Procedures for preparation of methyl esters and gas chromatography conditions were as described in Beaulieu et al. (2002). Identification of tissue LCFA was based on the retention time of known standards and is therefore presumptive. For hepatic PL, the LCFA profiles were used to calculate the unsaturation index as described by Luo et al. (1996).

\section{Statistical Analysis}

Based on expected variation in tissue fatty acid composition, our goal was to have at least 6 cows per treatment group. Of the 30 cows originally assigned to the experiment, 6 were assigned to CA, 7 each to $\mathrm{CR}$ and $\mathrm{S}$, and 10 to $\mathrm{U}$. The greater number of cows assigned to treatment $U$ was in anticipation of some cows not recovering well from surgery for rumen cannulation. The total number of cows from which data were analyzed was 25 , with $\mathrm{n}=5$ for CA, $\mathrm{n}=7$ for $\mathrm{CR}, \mathrm{n}=6$ for $\mathrm{S}$, and $\mathrm{n}=7$ for $\mathrm{U}$. One cow was removed from CA after calving with twins, undergoing surgery for left abomasal displacement, and developing a cascade of other postpartum health problems. One cow assigned to $\mathrm{S}$ aborted before the experimental period started and was not replaced. Three cows were removed from group U for various reasons: poor wound healing from cannulation, with subsequent rumenitis and peritonitis (1); severe coliform mastitis at calving necessitating euthanasia (1); and uterine torsion at parturition necessitating euthanasia (1).

Data were subjected to ANOVA for a repeated measures design by using the MIXED (Littell et al., 1996) procedure of SAS (Release 8.2; SAS Institute Inc., Cary, NC). The model contained the effects of dietary treatment (CA, CR, S, or U), cow nested within dietary treatment, time (as a repeated factor), and the interaction of diet $\times$ time; cow nested within treatment was designated as a random effect and was used as the error term to test the effect of dietary treatments. Several covariance structures were examined and the one that provided the Akaike information criterion closest to zero was used (Littell et al., 1996); in all cases, this was the autoregressive heterogeneous order 1 . Treatment effects were separated by use of nonorthogonal contrasts for 1) the effect of the degree of saturation of the supplemental fat source (S vs. U), 2) the effect of 
TISSUE FATTY ACIDS IN PERIPARTURIENT COWS

Table 3. Mean chemical composition ${ }^{1}$ and standard deviations of diets fed to dry and lactating cows

\begin{tabular}{lccrr}
\hline & \multicolumn{4}{c}{ Diet $^{2}$} \\
\cline { 2 - 5 } Component & \multicolumn{1}{c}{$\mathrm{C}$} & $\mathrm{S}$ & $\mathrm{U}$ & Lactation \\
\hline $\mathrm{DM}, \%$ & $66.9 \pm 1.5$ & $67.6 \pm 1.6$ & $66.0 \pm 1.7$ & $66.4 \pm 0.7$ \\
$\mathrm{NE}_{\mathrm{L}}{ }^{3} \mathrm{Mcal} / \mathrm{kg}$ of DM & $1.59 \pm 0.01$ & $1.71 \pm 0.01$ & $1.54 \pm 0.003$ & $1.73 \pm 0.01$ \\
$\mathrm{NE}_{\mathrm{L}},{ }^{4} \mathrm{Mcal} / \mathrm{kg}$ of DM & $1.50 \pm 0.01$ & $1.63 \pm 0.01$ & $1.46 \pm 0.003$ & $1.63 \pm 0.01$ \\
\cline { 2 - 5 } & & & & \\
$\mathrm{CP}$ & $14.9 \pm 0.8$ & $15.3 \pm 0.4$ & $16.4 \pm 0.5$ & $18.0 \pm 0.4$ \\
$\mathrm{ADF}$ & $28.0 \pm 1.2$ & $26.5 \pm 2.2$ & $27.3 \pm 1.3$ & $21.1 \pm 1.4$ \\
$\mathrm{NDF}$ & $40.0 \pm 1.41$ & $38.1 \pm 2.0$ & $39.0 \pm 1.0$ & $31.2 \pm 1.9$ \\
$\mathrm{NFC}$ & $32.2 \pm 0.8$ & $27.6 \pm 1.8$ & $29.6 \pm 0.8$ & $36.1 \pm 1.1$ \\
$\mathrm{Ca}$ & $1.03 \pm 0.07$ & $0.96 \pm 0.09$ & $1.18 \pm 0.07$ & $1.12 \pm 0.11$ \\
$\mathrm{P}$ & $0.51 \pm 0.01$ & $0.49 \pm 0.03$ & $0.57 \pm 0.03$ & $0.54 \pm 0.02$ \\
$\mathrm{Mg}$ & $0.42 \pm 0.02$ & $0.39 \pm 0.02$ & $0.47 \pm 0.03$ & $0.33 \pm 0.02$ \\
$\mathrm{~K}$ & $1.31 \pm 0.13$ & $1.31 \pm 0.10$ & $1.36 \pm 0.10$ & $1.54 \pm 0.08$ \\
$\mathrm{Na}$ & $0.19 \pm 0.01$ & $0.15 \pm 0.01$ & $0.20 \pm 0.004$ & $0.42 \pm 0.05$ \\
Ether extract & $2.7 \pm 0.3$ & $6.4 \pm 0.6$ & $2.4 \pm 0.3$ & $4.7 \pm 0.5$ \\
\hline
\end{tabular}

${ }^{1}$ Calculated from analyses of individual ingredients in rations. For dry period diets, $\mathrm{n}=6$ and for lactation $\operatorname{diet} \mathrm{n}=13$.

${ }^{2}$ Control diet (C) containing no supplemental fat fed to meet $120 \%(\mathrm{CA})$ or $80 \%$ (CR) of the $\mathrm{NE}_{\mathrm{L}}$ requirement for dry cows (NRC, 1989); $\mathrm{S}$ = diet containing mostly saturated fatty acids and fed to meet $120 \%$ of the $\mathrm{NE}_{\mathrm{L}}$ requirement; $\mathrm{U}=$ diet supplemented with soybean oil that was infused directly into the abomasum and fed to meet $120 \%$ of the $\mathrm{NE}_{\mathrm{L}}$ requirement.

${ }^{3}$ Calculated by the Dairy Herd Improvement Forage Testing Laboratory using NRC (1989) energy equations.

${ }^{4}$ Calculated using the NRC (2001) model.

${ }^{5} \mathrm{NFC}=100-\mathrm{NDF} \%-\mathrm{CP} \%-$ ether extract $\%-$ ash $\%$.

supplementing fat ( $\mathrm{S}$ or $\mathrm{U}$ ) to the dry period diet (S and U vs. CA), and 3) the effect of feeding the control diet at either 80 or $120 \%$ of the $\mathrm{NE}_{\mathrm{L}}$ requirements (CA vs. $\mathrm{CR}$ ). For repeated measurements, significant time and treatment $\times$ time effects were separated by use of the probability of difference (PDIFF) statement in SAS.

Separate ANOVA were conducted for BCS, BW, DMI, $\mathrm{NE}_{\mathrm{L}}$ intake, and weekly concentrations of glucose, NEFA, and BHBA in plasma during the prepartum period ( -40 d relative to expected calving to $-1 \mathrm{~d}$ relative to actual calving) and postpartum period (calving to 70 $\mathrm{d}$ after calving). An additional analysis was conducted for concentrations of glucose, NEFA, and BHBA in plasma by days of sampling for the period of $-21 \mathrm{~d}$ through $-1 \mathrm{~d}$ relative to calving and for the period of parturition through $21 \mathrm{~d}$ postpartum. Data for BW, BCS, concentrations of glucose, NEFA, and BHBA in plasma, contents of total lipids and glycogen in liver, and profiles of LCFA in liver PL and TG were adjusted by analysis of covariance using the respective data obtained at $-45 \mathrm{~d}$ before expected parturition. Correlation coefficients were generated using the PROC CORR procedure of SAS between each of the LCFA detected in the PL and TG fractions and concentrations of total lipids in liver tissue at $\mathrm{d} 1$ postpartum.

Least squares means were computed and are presented throughout. Significance was declared at $P \leq$ 0.05 and trends discussed when $P>0.05$ but $P<0.15$.
Data were tabulated as means by dry period treatments (across all days) and by day of measurement (across all treatments). Variables with significant treatment $x$ time interactions are shown graphically. Because the major objective was to determine the effects of dry period treatments on LCFA profiles of hepatic PL at calving, treatment means for $\mathrm{d} 1$ also are presented separately.

\section{RESULTS AND DISCUSSION}

\section{Intake and Production Variables}

The number of cows used in this study was based on the ability to detect differences in LCFA composition of tissues; it was not our objective to make inferences about effects of the prepartum diets on postpartum performance or health. Data are presented here to place the LCFA and other metabolic data in context and facilitate its interpretation.

Dry cows received the dietary treatments for an average of $42.5 \pm 5.4 \mathrm{~d}$ before parturition. The analyzed chemical composition of the diets is shown in Table 3. Diets were formulated and fed using NRC (1989) energy standards to allow intake of $120 \%$ (CA, S, and U) or $80 \%$ of calculated $\mathrm{NE}_{\mathrm{L}}$ requirements during the latter portion of the dry period. Limiting DMI to provide no more than $120 \%$ of $\mathrm{NE}_{\mathrm{L}}$ requirements resulted in lower 
Table 4. Least squares means for intakes of $\mathrm{DM}$ and $\mathrm{NE}_{\mathrm{L}}, \mathrm{BCS}$, and $\mathrm{BW}$ during the pre- and postpartum periods, calf birth weights, and milk production and composition for cows assigned to treatment groups CA, $\mathrm{CR}, \mathrm{S}$, and $\mathrm{U}$ during the last $40 \mathrm{~d}$ of the dry period

\begin{tabular}{|c|c|c|c|c|c|c|c|c|}
\hline \multirow[b]{3}{*}{ Variable } & \multirow{2}{*}{\multicolumn{4}{|c|}{ Dry period diet ${ }^{1}$}} & \multirow{3}{*}{$\begin{array}{c}\text { Largest } \\
\text { SEM }\end{array}$} & \multicolumn{3}{|c|}{ Contrast, $P$} \\
\hline & & & & & & & $\mathrm{S}+\mathrm{U}$ & CA vs. \\
\hline & $\mathrm{CA}$ & $\mathrm{CR}$ & $\mathrm{S}$ & $\mathrm{U}$ & & S vs. U & vs. CA & CR \\
\hline \multicolumn{9}{|l|}{ DMI, kg } \\
\hline Prepartum $^{2}$ & 10.9 & 7.7 & 10.0 & $8.0^{3}$ & 0.5 & 0.01 & 0.01 & 0.001 \\
\hline Postpartum ${ }^{4}$ & 20.2 & 18.3 & 18.5 & 20.2 & 1.4 & 0.32 & 0.58 & 0.30 \\
\hline \multicolumn{9}{|l|}{$\mathrm{NE}_{\mathrm{L}}$ intake ${ }^{5} \mathrm{Mcal} / \mathrm{d}$} \\
\hline Prepartum & 16.2 & 11.6 & 16.3 & $13.7^{6}$ & 1.0 & 0.01 & 0.12 & 0.001 \\
\hline Postpartum & 32.8 & 30.0 & 30.3 & 32.8 & 2.7 & 0.30 & 0.64 & 0.32 \\
\hline \multicolumn{9}{|l|}{$\mathrm{BCS}$} \\
\hline Prepartum & 3.2 & 3.0 & 3.0 & 2.9 & 0.15 & 0.26 & 0.01 & 0.15 \\
\hline Postpartum & 2.5 & 2.2 & 2.2 & 2.2 & 0.28 & 0.76 & 0.17 & 0.14 \\
\hline \multicolumn{9}{|l|}{$\mathrm{BW}, \mathrm{kg}$} \\
\hline Prepartum & 696 & 680 & 684 & 695 & 13 & 0.38 & 0.53 & 0.18 \\
\hline Postpartum & 615 & 600 & 600 & 622 & 16 & 0.20 & 0.81 & 0.38 \\
\hline $\begin{array}{l}\text { Calf birth weight, kg } \\
\text { Milk }\end{array}$ & 44.3 & 43.5 & 43.4 & 45.6 & 2.2 & 0.43 & 0.93 & 0.79 \\
\hline Yield, kg/d & 39.9 & 34.4 & 33.6 & 35.7 & 2.59 & 0.52 & 0.10 & 0.12 \\
\hline Fat, \% & 3.14 & 3.65 & 3.54 & 3.32 & 0.17 & 0.27 & 0.14 & 0.03 \\
\hline Fat, kg/d & 1.27 & 1.28 & 1.23 & 1.23 & 0.10 & 0.98 & 0.72 & 0.95 \\
\hline Protein, \% & 2.90 & 2.99 & 2.99 & 2.96 & 0.08 & 0.72 & 0.45 & 0.38 \\
\hline Protein, kg/d & 1.18 & 1.05 & 1.04 & 1.09 & 0.07 & 0.63 & 0.21 & 0.21 \\
\hline
\end{tabular}

${ }^{1}$ Control diet containing no supplemental fat fed to meet $120 \%(\mathrm{CA})$ or $80 \%(\mathrm{CR})$ of the $\mathrm{NE}_{\mathrm{L}}$ requirement for dry cows (NRC, 1989); $\mathrm{S}$ = diet containing mostly saturated fatty acids and fed to meet $120 \%$ of the $\mathrm{NE}_{\mathrm{L}}$ requirement; $\mathrm{U}=$ diet supplemented with soybean oil that was infused directly into the abomasum and fed to meet $120 \%$ of the $\mathrm{NE}_{\mathrm{L}}$ requirement.

${ }^{2}$ Means of data during $\mathrm{d}-40$ to -1 relative to parturition.

${ }^{3}$ Intake of dietary DM only; cows also received $332 \mathrm{~g} / \mathrm{d}$ of soybean oil by abomasal infusion.

${ }^{4}$ Means of data during $\mathrm{d} 1$ to 70 postpartum.

${ }^{5}$ Calculated using the NRC (2001) model, using NRC values for energy content of lipid sources. The energy value for abomasally infused soybean oil was assumed to be the same as for dietary delivery.

${ }^{6}$ Includes dietary DMI plus abomasally infused soybean oil.

DMI for S, U, and CR than for CA, as planned (Table 4). Analysis using the model and assumptions in NRC (2001) showed that intakes of $\mathrm{NE}_{\mathrm{L}}$ averaged 119, 86, 122 , and $101 \%$ of calculated requirements for cows fed $\mathrm{CA}, \mathrm{CR}, \mathrm{S}$, and $\mathrm{U}$, respectively. Differences in mean BCS $(P=0.15)$ and BW $(P=0.18)$ between CA and CR (Table 4) did not achieve statistical significance but are consistent with the calculated negative energy balance for CR cows. Cows fed CA had higher mean BCS during the last $40 \mathrm{~d}$ of the dry period than cows fed supplemental fats, although BW was not different among treatment groups. The lower BCS for cows fed U might be expected given the difference in prepartum $\mathrm{NE}_{\mathrm{L}}$ intake, but an explanation for cows fed $\mathrm{S}$ is difficult to postulate because energy intakes were essentially equal between $\mathrm{CA}$ and $\mathrm{S}$.

Infusion of soybean oil into the abomasum (U) decreased prepartal DMI and $\mathrm{NE}_{\mathrm{L}}$ intake relative to cows fed S. A previous study from our laboratory that used a similar abomasal infusion protocol with soybean oil also noted decreased DMI (Litherland et al., 2005), as have other studies in which unsaturated oils (Gagliostro and Chilliard, 1991; Benson and Reynolds, 2001) or
LCFA (Drackley et al., 1992b; Christensen et al., 1994) were infused postruminally. These effects may be mediated through gut hormones such as glucagon-like peptide 1 (Benson and Reynolds, 2001; Litherland et al., 2005). We acknowledge that no sham-treated cannulated cows were assigned to treatments other than U; therefore, the possibility exists that at least some of the decrease in DMI for treatment $U$ might have been attributable to ruminal cannulation or abomasal infusion per se. However, we do not believe that these factors affected DMI because in previous studies we have obtained DMI $>25 \mathrm{~kg} / \mathrm{d}$ in lactating cows subjected to abomasal infusion of lipid mixtures (Drackley et al., 1992b).

Differences among treatments for intakes of DM and $\mathrm{NE}_{\mathrm{L}}$ during the postpartum period were not significant. Postpartum BCS and BW did not differ among groups. Calf birth weights (Table 4) were similar among treatment groups. Milk production (Table 4) tended to be higher for cows that were fed CA. Cows that remained in the CA group had no health disorders, whereas the numbers of postpartum health problems were variable among the other treatment groups. Given the number 
Table 5. Least squares means by dietary treatment for concentrations of compounds in plasma

\begin{tabular}{|c|c|c|c|c|c|c|c|c|c|}
\hline \multirow[b]{3}{*}{ Variable } & \multirow{2}{*}{\multicolumn{4}{|c|}{ Dry period diet ${ }^{1}$}} & \multirow{3}{*}{$\begin{array}{c}\text { Largest } \\
\text { SEM }\end{array}$} & \multicolumn{4}{|c|}{ Contrast, $P$} \\
\hline & & & & & & & $\mathrm{S}+\mathrm{U}$ & CA vs. & $\operatorname{Trt} x$ \\
\hline & CA & $\mathrm{CR}$ & $\mathrm{S}$ & $\mathrm{U}$ & & S vs. U & vs. CA & CR & week \\
\hline \multicolumn{10}{|l|}{ NEFA, $\mu \mathrm{Eq} / \mathrm{L}$} \\
\hline Prepartum ${ }^{2}$ & 233 & 328 & 299 & 323 & 31 & 0.58 & 0.05 & 0.04 & 0.09 \\
\hline Postpartum $^{3}$ & 325 & 341 & 325 & 288 & 58 & 0.62 & 0.78 & 0.84 & 0.73 \\
\hline \multicolumn{10}{|l|}{ BHBA, mg/dL } \\
\hline Prepartum & 3.6 & 4.6 & 3.8 & 4.0 & 0.43 & 0.76 & 0.61 & 0.09 & 0.43 \\
\hline Postpartum & 4.7 & 5.2 & 4.0 & 3.8 & 0.66 & 0.83 & 0.32 & 0.56 & 0.02 \\
\hline \multicolumn{10}{|l|}{ Glucose, mg/dL } \\
\hline Prepartum & 59.0 & 56.4 & 59.7 & 59.1 & 1.50 & 0.79 & 0.83 & 0.22 & 0.69 \\
\hline Postpartum & 55.5 & 58.2 & 59.3 & 59.5 & 2.42 & 0.96 & 0.19 & 0.41 & 0.76 \\
\hline \multicolumn{10}{|c|}{ Cholesterol, mg/dL } \\
\hline Prepartum & 92 & 104 & 131 & 151 & 11.5 & 0.03 & 0.001 & 0.09 & 0.001 \\
\hline Postpartum & 150 & 115 & 145 & 159 & 16.6 & 0.41 & 0.90 & 0.07 & 0.08 \\
\hline
\end{tabular}

\footnotetext{
${ }^{1}$ Control diet containing no supplemental fat fed to meet $120 \%(\mathrm{CA})$ or $80 \%(\mathrm{CR})$ of the $\mathrm{NE}_{\mathrm{L}}$ requirement for dry cows (NRC, 1989); $\mathrm{S}$ = diet containing mostly saturated fatty acids and fed to meet $120 \%$ of the $\mathrm{NE}_{\mathrm{L}}$ requirement; $\mathrm{U}=$ diet supplemented with soybean oil that was infused directly into the abomasum and fed to meet $120 \%$ of the $\mathrm{NE}_{\mathrm{L}}$ requirement.

${ }^{2}$ Mean of $\mathrm{d}-40$ to -1 relative to calving.

${ }^{3}$ Mean of $\mathrm{d} 1$ to $\mathrm{d} 65$ relative to calving.
}

of cows used, mean production variables may have been as highly influenced by the occurrence of health disorders within each treatment group as by prepartum nutrition. Milk fat content (Table 4) tended to be lower in cows fed CA than for cows previously supplemented with fat, and was higher for cows fed CR than those receiving CA. Yield of milk fat was similar among treatments. Contents and yields of protein and total solids also did not differ among treatments (Table 4).

\section{Metabolites in Plasma and Composition of Liver}

Prepartal concentrations of NEFA in plasma were elevated for cows fed CR, S, and U compared with CA, but NEFA did not differ among treatments during the postpartum period (Table 5). In addition, a tendency for an interaction of treatment and day (Figure 1A) revealed that plasma NEFA did not increase as early before parturition for $\mathrm{CA}$ as in the other groups. The increased prepartal NEFA for CR reflects the restricted $\mathrm{DMI}$ and deficient $\mathrm{NE}_{\mathrm{L}}$ intake (Table 4), similar to previous studies that used the same degree of feed restriction during the dry period (Dann et al., 2005; Douglas et al., 2006). In contrast, the greater NEFA for cows fed S or U likely was a direct result of the fat supplementation (Drackley, 1999).

Prepartal BHBA concentrations tended $(P=0.09)$ to be greater for CR than for CA (Table 5). Postpartum, the interaction of treatment and day was significant (Figure 1B) because BHBA remained lower for $U$ than for CA from d 5 through d 17 postpartum, whereas means for CR and S were intermediate. Plasma glucose did not differ among treatments either prepartum or postpartum (Table 5). The lower BHBA with similar NEFA and glucose concentrations suggests that hepatic LCFA metabolism was altered by abomasal supply of soybean oil. Lesser ketogenesis might have arisen from decreased carnitine palmitoyltransferase activity as a result of altered membrane fluidity (Kolodziej and Zammit, 1990b) or from PUFA-mediated changes in gene transcription for enzymes of LCFA oxidation or esterification (Jump, 2002).

During the dry period, total cholesterol concentration in plasma (Table 5) was greater for CR than for CA, and was greater for the fat-supplemented groups than CA. Cows given U had greater plasma cholesterol than those fed S. In a previous study, abomasal infusion of unsaturated LCFA also resulted in greater cholesterol concentrations than infusion of saturated LCFA (Christensen et al., 1994). Prepartal differences in plasma cholesterol persisted postpartum (Figure 1C). Feedrestricted cows tended $(P=0.09)$ to have greater cholesterol than those fed CA during the prepartal period, but after parturition cows previously fed CA tended $(P=0.07)$ to have greater cholesterol concentrations than those fed CR (Table 5, Figure 1C). Douglas et al. (2006) observed a similar reversal of pre- and postpartal cholesterol concentrations for cows fed in restricted amounts during the dry period. Reasons for these differences are unknown.

Despite the prepartal differences in plasma NEFA, analysis of liver tissue for total lipid concentration revealed no differences among treatment groups (Figure 2A). Concentrations of total lipids in liver increased similarly among groups around calving, although contents were numerically highest for cows in group $\mathrm{U}$ at $\mathrm{d}$ 

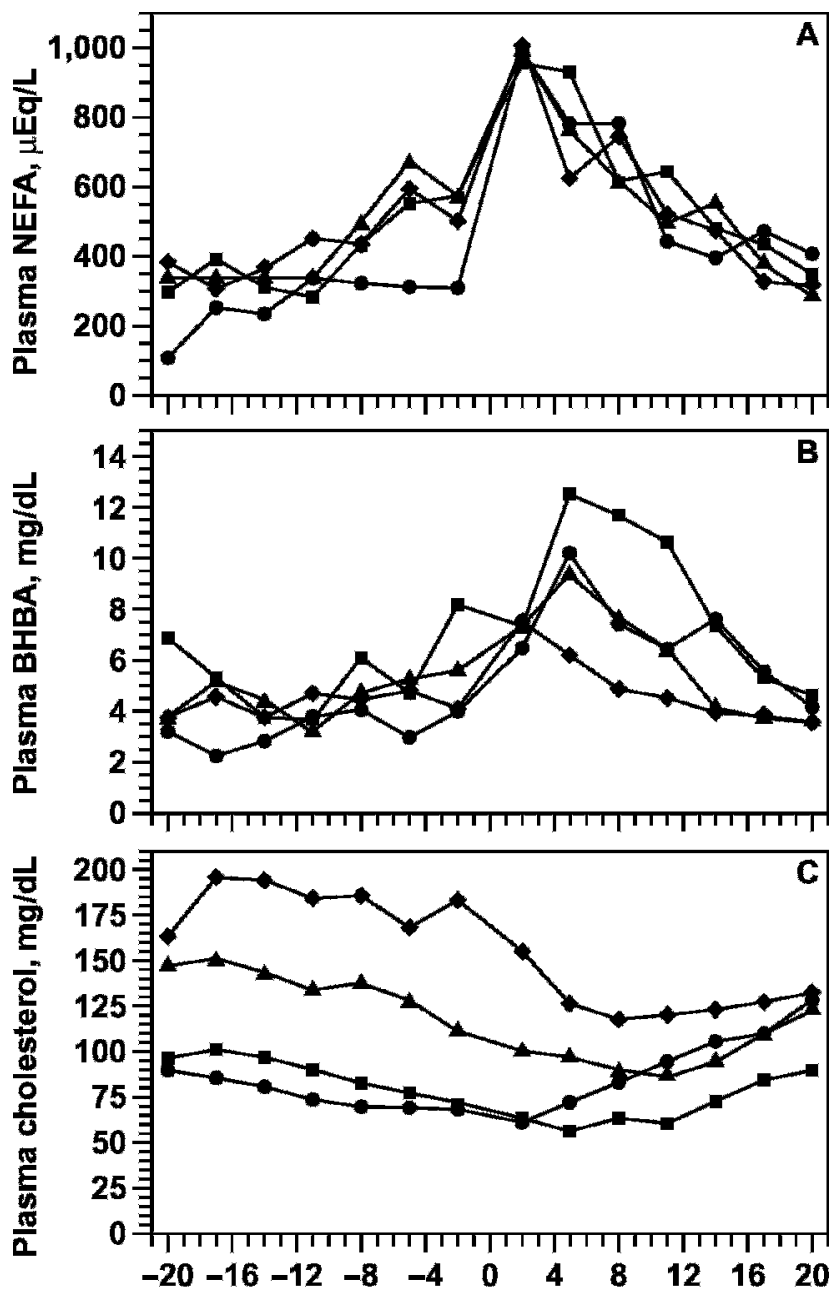

Day relative to parturition

Figure 1. Concentrations of NEFA (panel A), BHBA (panel B), and total cholesterol (panel C) in plasma from $20 \mathrm{~d}$ before parturition through $20 \mathrm{~d}$ postpartum for cows fed a control diet to meet $120 \%$ $(\mathrm{CA} ; \mathbf{O})$ or $80 \%(\mathrm{CR} ; \boldsymbol{\square})$ of $\mathrm{NE}_{\mathrm{L}}$ requirements, a diet containing supplemental saturated long-chain FFA (S; $\mathbf{\Delta})$, or a diet supplemented with abomasal infusion of soybean oil (U; ) during the last $40 \mathrm{~d}$ of the dry period. Panel A: For prepartum values, effects in the model included $\mathrm{S}$ vs. $\mathrm{U}(P=0.73), \mathrm{S}+\mathrm{U}$ vs. $\mathrm{CA}(P=0.003), \mathrm{CA}$ vs. $\mathrm{CR}(P=0.02)$, day $(P<0.001)$, and the interaction of treatment $\times$ day $(P=0.09)$. The SEM ranged from 61 to $148 \mu \mathrm{Eq} / \mathrm{L}$. For postpartum values, effects in the model included $\mathrm{S}$ vs. $\mathrm{U}(P=0.903), \mathrm{S}+\mathrm{U}$ vs. $\mathrm{CA}(P=0.76)$, CA vs. CR $(P=0.90)$, day $(P<0.001)$, and the interaction of treatment $\times$ day $(P=0.86)$. The SEM ranged from 62 to $166 \mu \mathrm{Eq} / \mathrm{L}$. Panel B: For prepartum values, effects in the model included $\mathrm{S}$ vs. U $(P=$ $0.75), \mathrm{S}+\mathrm{U}$ vs. $\mathrm{CA}(P=0.12), \mathrm{CA}$ vs. $\mathrm{CR}(P=0.01)$, day $(P=0.10)$, and the interaction of treatment $\times$ day $(P=0.30)$. The SEM ranged from 0.6 to $1.3 \mathrm{mg} / \mathrm{dL}$. For postpartum values, effects in the model included $\mathrm{S}$ vs. $\mathrm{U}(P=0.50), \mathrm{S}+\mathrm{U}$ vs. $\mathrm{CA}(P=0.39), \mathrm{CA}$ vs. $\mathrm{CR}(P=$ $0.33)$, day $(P<0.001)$, and the interaction of treatment $\times$ day $(P=$ $0.05)$. The SEM ranged from 0.7 to $1.4 \mathrm{mg} / \mathrm{dL}$. Panel C: For prepartum values, effects in the model included $\mathrm{S}$ vs. $\mathrm{U}(P<0.001), \mathrm{S}+\mathrm{U}$ vs. CA $(P<0.001)$, CA vs. CR $(P=0.24)$, day $(P<0.001)$, and the interaction of treatment $\times$ day $(P=0.05)$. The SEM ranged from 7.0 to $16.1 \mathrm{mg} / \mathrm{dL}$. For postpartum values, effects in the model included $\mathrm{S}$ vs. $\mathrm{U}(P=0.004), \mathrm{S}+\mathrm{U}$ vs. $\mathrm{CA}(P=0.03), \mathrm{CA}$ vs. $\mathrm{CR}(P=0.03)$ day $(P<0.001)$, and the interaction of treatment $\times$ day $(P<0.001)$. The SEM ranged from 4.0 to $10.3 \mathrm{mg} / \mathrm{dL}$.
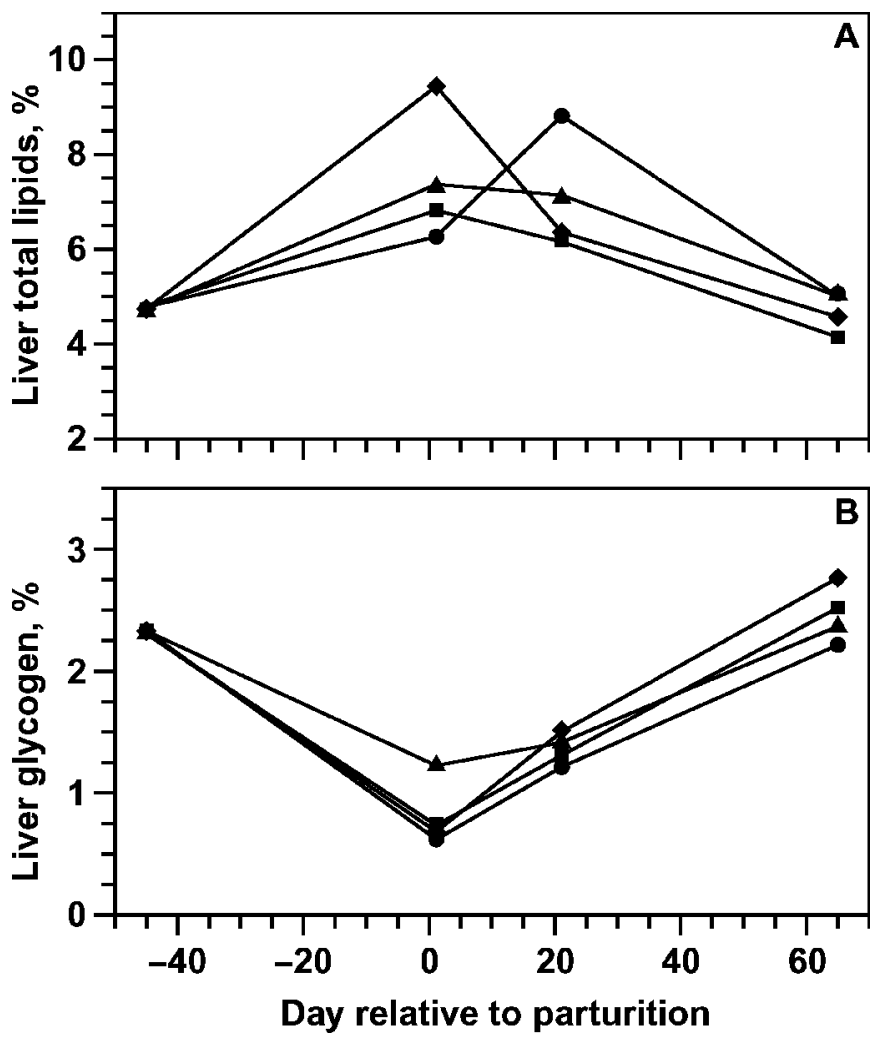

Figure 2. Concentrations of total lipids (panel A) and glycogen (panel B) as percentages of wet tissue weight for cows fed a control diet to meet $120 \%(\mathrm{CA} ;-)$ or $80 \%(\mathrm{CR} ; \mathbf{\square})$ of $\mathrm{NE}_{\mathrm{L}}$ requirements, a diet containing supplemental saturated long-chain FFA (S; $\mathbf{\Delta})$, or a diet supplemented with abomasal infusion of soybean oil (U; during the last $40 \mathrm{~d}$ of the dry period. Panel A: Largest SEM $=1.1 \%$. Effects in the model included S vs. U $(P=0.73), \mathrm{S}+\mathrm{U}$ vs. CA $(P=$ $0.94)$, CA vs. CR $(P=0.30)$, day $(P<0.001)$, and the interaction of treatment $\times$ day $(P=0.20)$. Panel B: Largest SEM $=0.35 \%$. Effects in the model included $\mathrm{S}$ vs. $\mathrm{U}(P=0.66), \mathrm{S}+\mathrm{U}$ vs. $\mathrm{CA}(P=0.18)$, CA vs. CR $(P=0.54)$, day $(P<0.10)$, and the interaction of treatment $\times$ day $(P=0.87)$.

1 and group CA at d 21 postpartum; at d 65 postpartum, contents for all groups decreased to those observed at d -45 prepartum. Concentrations of glycogen (Figure 2B) in liver also were similar among treatments, although the glycogen content decreased at calving; by $\mathrm{d}$ 65 , contents had increased to those observed at $d-45$ relative to calving. The lack of effect of supplemental fat treatments on peripartal total lipid content in liver agrees with previous studies from our laboratory (Douglas et al., 2004, 2006) as well as data from others (Skaar et al., 1989; Burhans and Bell, 1998).

\section{LCFA in Plasma}

The effect of prepartum dietary treatments on the profile of LCFA detected in plasma total lipids is shown in Table 6. Percentages of 14:0 and 20:4 in plasma were 
Table 6. Least squares means by dietary treatment for weight percentages of fatty acids detected in plasma

\begin{tabular}{|c|c|c|c|c|c|c|c|c|c|}
\hline \multirow[b]{3}{*}{ Fatty acid, \% } & \multirow{2}{*}{\multicolumn{4}{|c|}{ Dry period dietary treatment ${ }^{1}$}} & \multirow{3}{*}{$\begin{array}{c}\text { Largest } \\
\text { SEM }\end{array}$} & \multicolumn{4}{|c|}{ Contrast, $P$} \\
\hline & & & & & & \multirow[b]{2}{*}{$\mathrm{S}$ vs. U } & \multirow{2}{*}{$\begin{array}{l}\mathrm{S}+\mathrm{U} \\
\text { vs. CA }\end{array}$} & \multirow{2}{*}{$\begin{array}{c}\text { CA vs. } \\
\text { CR }\end{array}$} & \multirow{2}{*}{$\begin{array}{c}\text { Trt } \times \\
\text { day }\end{array}$} \\
\hline & CA & CR & $\mathrm{S}$ & $\mathrm{U}$ & & & & & \\
\hline \multicolumn{10}{|l|}{$14: 0$} \\
\hline Prepartum $^{2}$ & 0.96 & 0.57 & 0.69 & 0.35 & 0.27 & 0.09 & 0.01 & 0.05 & 0.02 \\
\hline Postpartum $^{3}$ & 0.71 & 0.56 & 0.68 & 0.44 & 0.22 & 0.14 & 0.11 & 0.18 & 0.05 \\
\hline \multicolumn{10}{|l|}{$14: 1$} \\
\hline Prepartum & 0.65 & 0.57 & 0.96 & 0.62 & 0.29 & 0.18 & 0.70 & 0.69 & 0.89 \\
\hline Postpartum & 0.47 & 0.47 & 0.58 & 0.75 & 0.24 & 0.46 & 0.21 & 0.99 & 0.78 \\
\hline \multicolumn{10}{|l|}{$16: 0$} \\
\hline Prepartum & 17.64 & 17.04 & 19.12 & 11.92 & 1.16 & 0.004 & 0.22 & 0.83 & 0.64 \\
\hline Postpartum & 15.80 & 16.79 & 15.76 & 12.05 & 1.08 & 0.08 & 0.14 & 0.66 & 0.05 \\
\hline \multicolumn{10}{|l|}{$16: 1$} \\
\hline Prepartum & 1.89 & 3.20 & 4.83 & 3.66 & 0.48 & 0.78 & 0.13 & 0.53 & 0.51 \\
\hline Postpartum & 2.67 & 4.07 & 4.76 & 5.17 & 0.42 & 0.83 & 0.21 & 0.48 & 0.12 \\
\hline \multicolumn{10}{|l|}{$18: 0$} \\
\hline Prepartum & 19.29 & 17.23 & 18.64 & 13.39 & 1.18 & 0.01 & 0.04 & 0.56 & 0.30 \\
\hline Postpartum & 15.24 & 15.80 & 15.03 & 12.16 & 1.10 & 0.08 & 0.12 & 0.89 & 0.24 \\
\hline \multicolumn{10}{|l|}{ Cis-18:1 } \\
\hline Prepartum & 16.43 & 16.10 & 16.90 & 14.15 & 1.20 & 0.44 & 0.69 & 0.84 & 0.32 \\
\hline Postpartum & 16.24 & 20.00 & 18.55 & 18.21 & 1.06 & 0.89 & 0.33 & 0.07 & 0.26 \\
\hline \multicolumn{10}{|l|}{$18: 2$} \\
\hline Prepartum & 31.04 & 35.51 & 24.38 & 54.55 & 1.86 & 0.0001 & 0.01 & 0.14 & 0.001 \\
\hline Postpartum & 38.17 & 37.85 & 40.85 & 43.47 & 1.77 & 0.28 & 0.04 & 0.88 & 0.02 \\
\hline \multicolumn{10}{|l|}{$18: 3$} \\
\hline Prepartum & 2.05 & 1.73 & 1.82 & 1.97 & 0.47 & 0.37 & 0.48 & 0.21 & 0.16 \\
\hline Postpartum & 1.94 & 1.48 & 1.86 & 2.14 & 0.44 & 0.29 & 0.78 & 0.24 & 0.32 \\
\hline \multicolumn{10}{|l|}{$20: 4$} \\
\hline Prepartum & 2.32 & 2.25 & 2.63 & 0.41 & 0.60 & 0.0001 & 0.03 & 0.80 & 0.01 \\
\hline Postpartum & 2.09 & 1.44 & 1.76 & 1.70 & 0.48 & 0.76 & 0.16 & 0.01 & 0.05 \\
\hline \multicolumn{10}{|l|}{$22: 0$} \\
\hline Prepartum & 4.44 & 5.09 & 3.99 & 2.15 & 0.78 & 0.006 & 0.04 & 0.24 & 0.01 \\
\hline Postpartum & 3.26 & 2.97 & 3.36 & 2.34 & 0.62 & 0.02 & 0.19 & 0.68 & 0.02 \\
\hline
\end{tabular}

${ }^{1}$ Control diet containing no supplemental fat fed to meet $120 \%$ (CA) or $80 \%$ (CR) of the $\mathrm{NE}_{\mathrm{L}}$ requirement for dry cows (NRC, 1989); $\mathrm{S}=$ diet containing mostly saturated fatty acids and fed to meet $120 \%$ of the $\mathrm{NE}_{\mathrm{L}}$ requirement; $\mathrm{U}=$ diet supplemented with soybean oil that was infused directly into the abomasum and fed to meet $120 \%$ of the $\mathrm{NE}_{\mathrm{L}}$ requirement.

${ }^{2}$ Prepartum values $(\mathrm{d}-21$ and -10$)$.

${ }^{3}$ Postpartum values (d 1 to 65 ).

lower for CR cows than for CA cows, but feed restriction did not affect other fatty acids. Abomasal infusion of soybean oil resulted in large increases of 18:2 relative to cows receiving diet $\mathrm{S}$ and decreased the percentages of 14:0, 16:0, 18:0, 20:4, and 22:0 relative to S. Percentages of LCFA in plasma presented by day of study across treatments are shown in Table 7. As calving approached, percentages of 14:0 and 16:0 increased; values peaked at $1 \mathrm{~d}$ postpartum and then decreased to values similar to those measured in the covariate sample by d 65 postpartum. Peripartal percentages of $14: 1,16: 1$, and 18:1 in plasma did not differ significantly from contents observed during the early treatment period. However, percentages of 18:0, 18:3, 20:4, and 22:0 transiently decreased at calving but then increased to contents observed before the initiation of treatments.

Significant interactions of treatment with day (Table 6) were detected for some fatty acids in plasma total lipids (Figures 3 and 4). The percentages of 14:0, 16:0, and 22:0 were lower during the dry period and into early lactation for cows fed U (Figure 3). The percentage of 18:2 increased sharply for cows receiving U during the dry period and remained higher than other treatments through parturition before decreasing precipitously once infusion was ceased (Figure 4A). For cows in groups CA, CR, and S, plasma 18:2 increased after parturition. In contrast to 18:2, the content of 20:4 decreased during the dry period for cows fed U (Figure 4B); cows fed CA, CR, or S had relatively constant percentages of 20:4 until dropping off markedly at parturition and then rebounding by $\mathrm{d} 21$.

The increased content of 18:2 in plasma for cows receiving $\mathrm{U}$ during the last $40 \mathrm{~d}$ of the dry period resulted from the high content of 18:2 in soybean oil that was infused directly into the abomasum. Normally, only small quantities of dietary PUFA reach the small intestine of ruminant animals because of extensive biohydrogenation in the rumen. The PUFA that are absorbed, 
Table 7. Least squares means by day relative to parturition for weight percentages of fatty acids in plasma

\begin{tabular}{|c|c|c|c|c|c|c|c|c|c|c|c|c|}
\hline \multirow{2}{*}{$\begin{array}{l}\text { Fatty acid, } \\
\%\end{array}$} & \multicolumn{3}{|c|}{ Day relative to calving } & \multirow{2}{*}{$\begin{array}{c}\text { Largest } \\
\text { SEM }^{2}\end{array}$} & \multirow[b]{2}{*}{$P^{2}$} & \multicolumn{5}{|c|}{ Day relative to calving } & \multirow{2}{*}{$\begin{array}{c}\text { Largest } \\
\text { SEM }^{3}\end{array}$} & \multirow[b]{2}{*}{$P^{3}$} \\
\hline & $-45^{1}$ & -21 & -10 & & & 1 & 10 & 21 & 45 & 65 & & \\
\hline $14: 0$ & 0.61 & 0.58 & 0.72 & 0.16 & 0.12 & $0.87^{\mathrm{a}}$ & $0.55^{\mathrm{bc}}$ & $0.50^{\mathrm{c}}$ & $0.57^{\mathrm{bc}}$ & $0.49^{\mathrm{c}}$ & 0.12 & 0.01 \\
\hline $16: 0$ & 16.69 & 15.45 & 17.78 & 0.58 & 0.13 & $18.23^{\mathrm{a}}$ & $17.04^{\mathrm{b}}$ & $14.46^{\mathrm{c}}$ & $12.73^{\mathrm{d}}$ & $12.23^{\mathrm{d}}$ & 0.49 & 0.001 \\
\hline $16: 1$ & 3.92 & 4.10 & 3.73 & 0.60 & 0.79 & 3.62 & 5.26 & 5.32 & 4.19 & 3.43 & 0.48 & 0.63 \\
\hline $18: 0$ & 16.52 & 17.08 & 17.53 & 0.96 & 0.59 & $15.57^{\mathrm{bc}}$ & $14.70^{\mathrm{c}}$ & $13.86^{\mathrm{c}}$ & $14.28^{\mathrm{c}}$ & $13.73^{\mathrm{c}}$ & 0.88 & 0.01 \\
\hline Cis-18:1 & 18.04 & 15.66 & 16.61 & 1.42 & 0.26 & $19.56^{\mathrm{ab}}$ & $21.16^{\mathrm{a}}$ & $20.14^{\mathrm{a}}$ & $18.21^{\mathrm{b}}$ & $14.45^{\mathrm{c}}$ & 1.35 & 0.05 \\
\hline $20: 4$ & 2.11 & 1.99 & 1.86 & 0.24 & 0.05 & $1.04^{\mathrm{c}}$ & $1.08^{\mathrm{c}}$ & $1.82^{\mathrm{b}}$ & $2.15^{\mathrm{b}}$ & $2.60^{\mathrm{a}}$ & 0.18 & 0.01 \\
\hline $22: 0$ & 4.14 & 4.00 & 3.90 & 0.30 & 0.56 & $3.21^{\mathrm{a}}$ & $3.45^{\mathrm{a}}$ & $3.14^{\mathrm{a}}$ & $2.35^{\mathrm{b}}$ & $2.58^{\mathrm{b}}$ & 0.26 & 0.01 \\
\hline
\end{tabular}

${ }^{\mathrm{a}-\mathrm{d}}$ Where the overall effect of day was significant $(P<0.05)$ within prepartum or postpartum analyses, means without a common superscript letter differ $(P<0.05)$.

${ }^{1}$ Mean of pretreatment values used as a covariate in statistical analysis.

${ }^{2}$ Prepartum values $(\mathrm{d}-21$ and -10$)$.

${ }^{3}$ Postpartum values (d 1 to 65 ).

especially 18:2, are preferentially incorporated into PL and cholesterol esters to increase the half-lives of these essential PUFA in blood lipids and ensure a steady supply to ruminant tissues (Noble, 1984). Increases in tissue contents of 18:2 and 18:3 are possible, if amounts of these LCFA reaching the small intestine exceed those normally encountered (Cook et al., 1972). Therefore, protecting PUFA from biohydrogenation in the rumen concomitantly alters the LCFA composition of lipids in the blood. For example, Delbecchi et al. (2001) reported increased contents of 18:2 and 18:3 in plasma from midlactation cows fed a TMR containing $4.8 \%$ formaldehyde-protected canola seeds.

The marked decrease in the percentage of 20:4 observed in plasma lipids from cows in group $U$ (Figure 4B) probably resulted from the increased prevalence of 18:2 absorbed from the small intestine. Increased availability of 18:2 might have competed with $20: 4$ for esterification in the $s n-2$ position of phosphatidylcholine (Jenkins et al., 1988). Moreover, 18:2 may have inhibited the activity of the $\Delta^{5}$ - and $\Delta^{6}$-desaturases that produce 20:4 from 18:2 (Spector, 2000) as reported in calves by Jenkins (1988). However, these mechanisms were not determined directly in our experiment. The smaller percentage of 20:4 in plasma lipids for cows in the $U$ treatment group also could be attributable in part to the greater cholesterol concentrations in plasma (Table 5, Figure 1). Because 18:2 dominates the fatty acid composition of bovine cholesterol esters (Jenkins et al., 1988), the relative proportions of other fatty acids such as 20:4 in plasma may have been diluted by a greater concentration of cholesterol esters enriched in 18:2.

Although the proportion of 20:4 was lower in cows from group U, the actual amount of 20:4 (or any other LCFA) in plasma was not quantified so it is unknown whether the availability of 20:4 from tissue synthesis or intestinal absorption was significantly altered. Little 20:4 is consumed in the diet, but sufficient 18:2 is believed to escape biohydrogenation in the rumen to provide precursor for the production of 20:4 needed by ruminants (Noble, 1984). Proportions of 20:4 in plasma total lipids also were decreased in cows that were fed CR. Therefore, decreased contents of 20:4 for cows in group U might have been attributable, at least in part, to lower DMI.

\section{LCFA in Adipose Tissue Lipids}

Changes in proportions of LCFA in plasma were reflected in the LCFA profiles of adipose tissue biopsied at $d 1$ postpartum (Table 8). The profile of LCFA was similar to that reported by Rukkwamsuk et al. (2000) for cows at 0.5 wk after parturition. Contents of 14:0 in adipose tissue were significantly decreased for cows in group CR, which was likely a result of the lower availability of precursors for de novo LCFA synthesis in adipose tissue but also perhaps to the lower contents of 14:0 in plasma. Feed restriction resulted in greater proportions of 18:1 in adipose tissue compared with cows fed CA. The reason for this change is unclear but could be a result of greater desaturation of $18: 0$ because 18:0 was numerically decreased in adipose lipids. Compared with cows of group U, cows fed S also had significantly increased 18:1, which probably resulted from desaturation of the increased amounts of 18:0 reaching adipose tissue.

Abomasal infusion of soybean oil during the last 40 $\mathrm{d}$ of the dry period increased contents of 18:2 and 18:3 and decreased contents of 18:1 and 20:0 in adipose tissue lipids at $d 1$ postpartum compared with adipose from cows fed CA or S. These data indicate that it is 

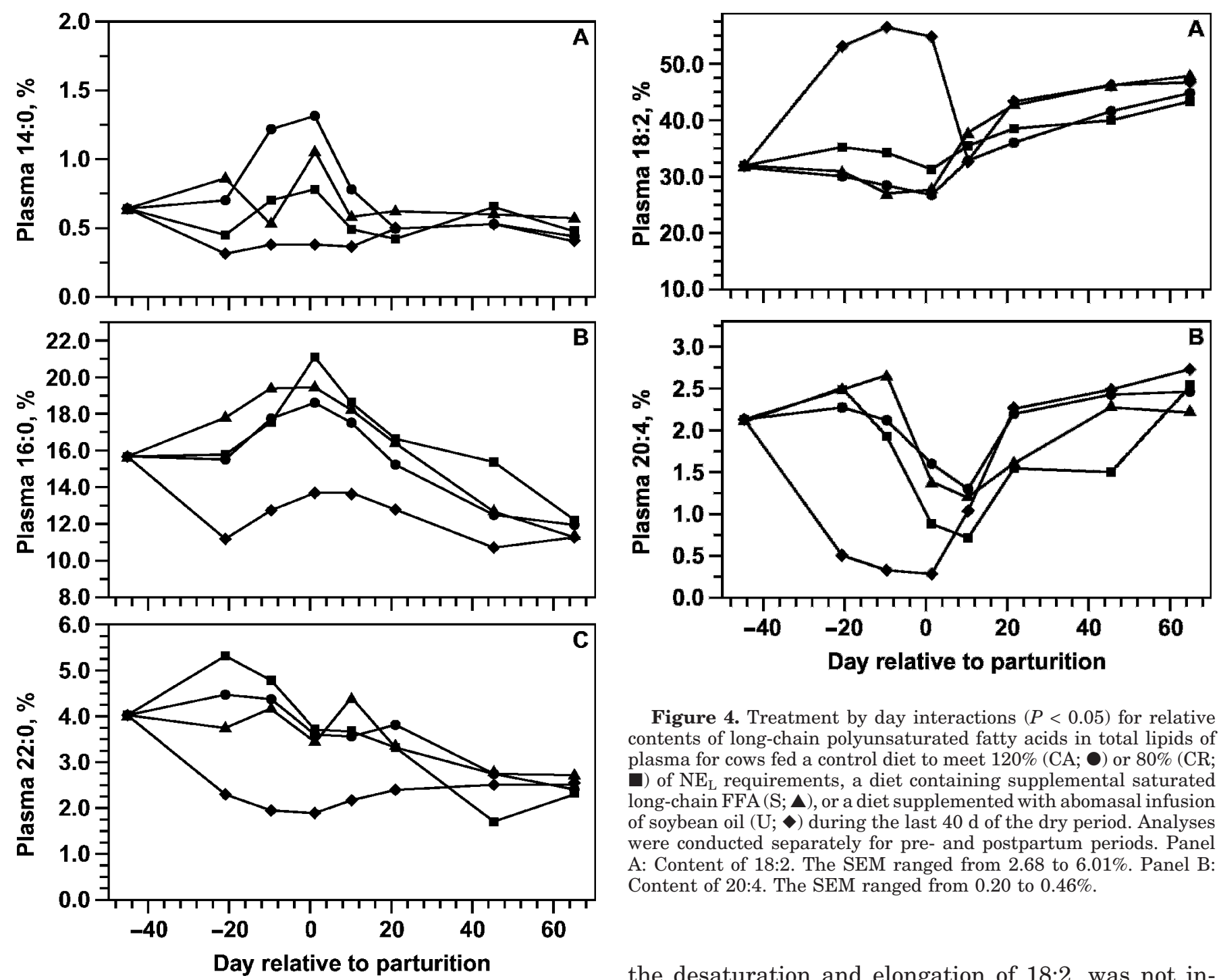

Figure 4. Treatment by day interactions $(P<0.05)$ for relative contents of long-chain polyunsaturated fatty acids in total lipids of plasma for cows fed a control diet to meet $120 \%$ (CA; 0 ) or $80 \%$ (CR; 口) of $\mathrm{NE}_{\mathrm{L}}$ requirements, a diet containing supplemental saturated long-chain FFA (S; $\mathbf{\Delta}$ ), or a diet supplemented with abomasal infusion of soybean oil (U; ) during the last $40 \mathrm{~d}$ of the dry period. Analyses were conducted separately for pre- and postpartum periods. Panel A: Content of 18:2. The SEM ranged from 2.68 to $6.01 \%$. Panel B: Content of 20:4. The SEM ranged from 0.20 to $0.46 \%$.

Figure 3. Treatment $\times$ day interactions $(P<0.05$ unless noted $)$ for relative contents of long-chain saturated fatty acids in total lipids of plasma for cows fed a control diet to meet $120 \%(\mathrm{CA}$; ) or $80 \%$ $\left(\mathrm{CR}\right.$; ) of $\mathrm{NE}_{\mathrm{L}}$ requirements, a diet containing supplemental saturated long-chain FFA $(\mathrm{S} ; \boldsymbol{\Delta})$, or a diet supplemented with abomasal infusion of soybean oil (U; $\bullet$ ) during the last $40 \mathrm{~d}$ of the dry period. Analyses were conducted separately for pre- and postpartum periods. Panel A: Content of 14:0. The SEM ranged from 0.10 to $0.16 \%$. Panel B: Content of 16:0. The SEM ranged from 0.65 to $1.04 \%$. The interaction of treatment $\times$ day was not significant $(P=0.64)$ for the prepartum period. Panel C: Content of 22:0. The SEM ranged from 0.29 to $0.47 \%$.

feasible to alter the LCFA composition of adipose tissue via nutritional manipulation during the relatively short time of the dry period. Chilliard et al. (1991) also reported increases in contents of 18:2 and 18:3 in adipose tissue following infusion of $1.1 \mathrm{~kg} / \mathrm{d}$ of rapeseed oil into the duodenum. Despite the increases in 18:2 in adipose, however, the content of $20: 3 n-6$, which is produced from

the desaturation and elongation of 18:2, was not increased above trace amounts and 20:4 was not detected.

\section{LCFA in Hepatic PL}

The total PL content of liver increases progressively from d 14 to $d 56$ postpartum (Drackley et al., 1992a) but does not change appreciably during the development of fatty liver (Collins and Reid, 1980; Herdt et al., 1983). Therefore, percentages of LCFA in hepatic PL reported here should approximate their actual abundance in the liver. Moderate feed restriction during the dry period had only minor effects on hepatic PL composition (Table 9). Cows fed CR had lower 16:1, tended $(P=0.07)$ to have higher $18: 2$, and tended $(P=0.15)$ to have lower 16:0 in hepatic PL than did cows fed CA, although the reason for these small changes is not obvious.

Cows fed supplemental fat had more pronounced changes in hepatic PL composition (Table 9). Cows fed $\mathrm{S}$ or $\mathrm{U}$ had lower $16: 1$ and tended $(P=0.06)$ to have 
Table 8. Least squares means by dietary treatment for weight percentages of fatty acids in adipose tissue biopsied at $1 \mathrm{~d}$ postpartum

\begin{tabular}{|c|c|c|c|c|c|c|c|c|c|}
\hline \multirow{3}{*}{$\begin{array}{l}\text { Fatty acid, } \\
\%\end{array}$} & \multirow[b]{3}{*}{$\mathrm{d}-45^{1}$} & \multirow{2}{*}{\multicolumn{4}{|c|}{ Dry period diet ${ }^{2}$}} & \multirow{3}{*}{$\begin{array}{c}\text { Largest } \\
\text { SEM }\end{array}$} & \multicolumn{3}{|c|}{ Contrast, $P$} \\
\hline & & & & & & & & $\mathrm{S}+\mathrm{U}$ & $\mathrm{CA}$ \\
\hline & & $\mathrm{CA}$ & $\mathrm{CR}$ & $\mathrm{S}$ & $\mathrm{U}$ & & $\mathrm{S}$ vs. $\mathrm{U}$ & vs. CA & CR \\
\hline $14: 0$ & 2.64 & 2.96 & 2.07 & 2.55 & 2.90 & 0.29 & 0.29 & 0.55 & 0.04 \\
\hline $14: 1$ & 1.22 & 1.18 & 1.07 & 1.15 & 1.19 & 0.12 & 0.76 & 1.00 & 0.56 \\
\hline $16: 0$ & 26.98 & 27.98 & 29.86 & 26.84 & 27.70 & 2.33 & 0.71 & 0.88 & 0.52 \\
\hline $16: 1$ & 6.70 & 6.45 & 5.40 & 6.41 & 6.50 & 0.80 & 0.86 & 0.95 & 0.39 \\
\hline $18: 0$ & 10.68 & 10.63 & 8.78 & 10.94 & 12.74 & 1.54 & 0.36 & 0.50 & 0.42 \\
\hline Cis-18:1 & 48.55 & 47.65 & 50.54 & 49.02 & 45.01 & 0.86 & 0.01 & 0.86 & 0.01 \\
\hline Trans-18:1 & 0.84 & 0.87 & 0.58 & 0.82 & 0.85 & 0.19 & 0.88 & 0.93 & 0.32 \\
\hline $18: 2$ & 1.95 & 1.78 & 1.29 & 1.77 & 2.66 & 0.22 & 0.06 & 0.11 & 0.14 \\
\hline $18: 3$ & 0.15 & 0.15 & 0.11 & 0.11 & 0.23 & 0.33 & 0.05 & 0.48 & 0.59 \\
\hline 20.0 & 0.07 & 0.08 & 0.08 & 0.12 & 0.06 & 0.02 & 0.05 & 0.85 & 0.78 \\
\hline $20: 1$ & 0.16 & 0.21 & 0.14 & 0.18 & 0.14 & 0.03 & 0.43 & 0.23 & 0.19 \\
\hline $20: 2$ & 0.06 & 0.05 & 0.05 & 0.08 & Trace $^{3}$ & 0.02 & 0.19 & 0.77 & 0.87 \\
\hline $20: 3$ & Trace & Trace & Trace & Trace & $\mathrm{ND}^{4}$ & - & - & - & - \\
\hline
\end{tabular}

${ }^{1}$ Mean of pretreatment values used as covariate in statistical analysis.

${ }^{2}$ Control diet containing no supplemental fat fed to meet $120 \%(\mathrm{CA})$ or $80 \%(\mathrm{CR})$ of the $\mathrm{NE}_{\mathrm{L}}$ requirement for dry cows (NRC, 1989); $\mathrm{S}=$ diet containing mostly saturated fatty acids and fed to meet $120 \%$ of the $\mathrm{NE}_{\mathrm{L}}$ requirement; $\mathrm{U}=$ diet supplemented with soybean oil that was infused directly into the abomasum and fed to meet $120 \%$ of the $\mathrm{NE}_{\mathrm{L}}$ requirement.

${ }^{3}$ Trace amounts $(<0.05 \%)$ of fatty acid were detected in the samples.

${ }^{4}$ Not detected in samples.

higher 20:0 than cows fed CA. Infusion of $\mathrm{U}$ resulted in greater 18:2, 20:0, and 20:2 but lower 20:4 and 26:0 than cows fed S. Significant interactions of treatment $\times$ day (Figures 5 and 6 ) revealed that these changes were pronounced on 1 postpartum but then were reversed by $\mathrm{d} 21$ and 65 . Cows fed $\mathrm{S}$ had lower contents

Table 9. Least squares means by dietary treatment for weight percentages of fatty acids detected in phospholipid fractions of liver tissue biopsied at 1,21 , and $65 \mathrm{~d}$ relative to calving

\begin{tabular}{|c|c|c|c|c|c|c|c|c|c|}
\hline \multirow{3}{*}{$\begin{array}{l}\text { Fatty acid, } \\
\%\end{array}$} & \multirow{2}{*}{\multicolumn{4}{|c|}{ Dry period diet ${ }^{1}$}} & \multirow{3}{*}{$\begin{array}{c}\text { Largest } \\
\text { SEM }\end{array}$} & \multicolumn{3}{|c|}{ Contrast, $P$} & \multirow{3}{*}{$\begin{array}{l}\text { Trt } \times \\
\text { day }\end{array}$} \\
\hline & & & & & & \multirow[b]{2}{*}{ S vs. U } & \multirow{2}{*}{$\begin{array}{l}\mathrm{S}+\mathrm{U} \\
\text { vs. CA }\end{array}$} & \multirow{2}{*}{$\begin{array}{c}\text { CA vs. } \\
\text { CR }\end{array}$} & \\
\hline & CA & CR & $\mathrm{S}$ & $\mathrm{U}$ & & & & & \\
\hline $16: 0$ & 14.54 & 12.67 & 13.93 & 13.20 & 0.97 & 0.58 & 0.36 & 0.15 & 0.69 \\
\hline $16: 1$ & 1.73 & 0.81 & 0.85 & 0.67 & 0.28 & 0.57 & 0.02 & 0.02 & 0.14 \\
\hline 18:0 & 31.28 & 32.31 & 31.48 & 32.14 & 1.17 & 0.55 & 0.82 & 0.54 & 0.13 \\
\hline Cis-18:1 & 19.39 & 19.83 & 18.08 & 16.42 & 1.19 & 0.32 & 0.14 & 0.80 & 0.01 \\
\hline Trans-18:1 & 0.60 & 0.49 & 0.40 & 0.51 & 0.11 & 0.43 & 0.30 & 0.48 & 0.06 \\
\hline $18: 2$ & 10.82 & 12.46 & 11.49 & 16.73 & 0.65 & 0.001 & 0.007 & 0.07 & 0.01 \\
\hline 18:3 & 0.09 & 0.12 & 0.20 & 0.06 & 0.05 & 0.02 & 0.54 & 0.78 & 0.12 \\
\hline 20.0 & 0.24 & 0.38 & 0.30 & 0.59 & 0.09 & 0.01 & 0.06 & 0.22 & 0.29 \\
\hline $20: 1$ & 0.08 & 0.08 & 0.11 & 0.12 & 0.07 & 0.86 & 0.70 & 0.97 & 0.83 \\
\hline $20: 2$ & 0.08 & 0.06 & 0.09 & 0.14 & 0.29 & 0.05 & 0.22 & 0.95 & 0.51 \\
\hline $20: 3$ & 6.49 & 5.53 & 5.97 & 5.16 & 0.67 & 0.36 & 0.25 & 0.29 & 0.03 \\
\hline $20: 4$ & 10.30 & 11.03 & 10.96 & 9.20 & 0.58 & 0.02 & 0.68 & 0.36 & 0.01 \\
\hline $20: 5$ & 0.24 & 0.35 & 0.42 & 0.44 & 0.12 & 0.87 & 0.18 & 0.45 & 0.47 \\
\hline $22: 0$ & Trace $^{2}$ & $\mathrm{ND}^{3}$ & ND & Trace & - & - & - & - & -- \\
\hline $22: 5$ & 0.53 & 0.44 & 1.41 & 1.25 & 0.83 & 0.78 & 0.15 & 0.85 & 0.47 \\
\hline $22: 6$ & 2.51 & 2.36 & 2.98 & 2.46 & 0.32 & 0.19 & 0.63 & 0.72 & 0.01 \\
\hline $24: 0$ & 0.89 & 0.72 & 0.95 & 0.78 & 0.21 & 0.53 & 0.92 & 0.53 & 0.05 \\
\hline $26: 0$ & 0.18 & 0.36 & 0.38 & 0.14 & 0.11 & 0.04 & 0.53 & 0.21 & 0.59 \\
\hline
\end{tabular}

${ }^{1}$ Control diet containing no supplemental fat fed to meet $120 \%(\mathrm{CA})$ or $80 \%(\mathrm{CR})$ of the $\mathrm{NE}_{\mathrm{L}}$ requirement for dry cows (NRC, 1989); $\mathrm{S}$ = diet containing mostly saturated fatty acids and fed to meet $120 \%$ of the $\mathrm{NE}_{\mathrm{L}}$ requirement; $\mathrm{U}=$ diet supplemented with soybean oil that was infused directly into the abomasum and fed to meet $120 \%$ of the $\mathrm{NE}_{\mathrm{L}}$ requirement.

${ }^{2}$ Trace amounts $(<0.05 \%)$ were detected in samples.

${ }^{3}$ Not detected in samples. 


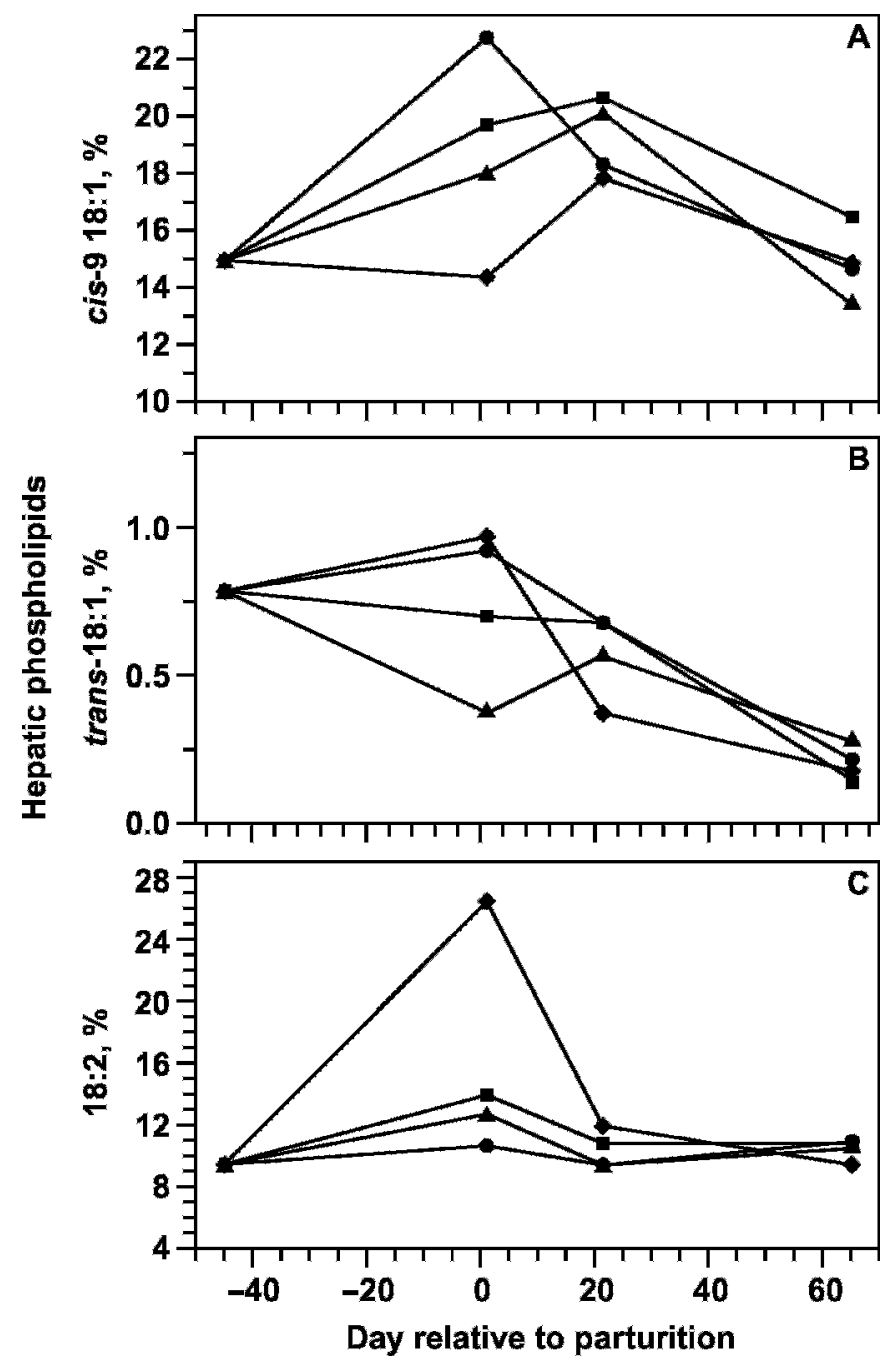

Figure 5. Treatment $\times$ day interactions $(P<0.05)$ for relative contents of 18-carbon unsaturated fatty acids in phospholipids from liver for cows fed a control diet to meet $120 \%(\mathrm{CA} ; \mathbf{O})$ or $80 \%(\mathrm{CR}$; -) of $\mathrm{NE}_{\mathrm{L}}$ requirements, a diet containing supplemental saturated long-chain FFA $(\mathrm{S} ; \boldsymbol{\Delta})$, or a diet supplemented with abomasal infusion of soybean oil (U; ) during the last $40 \mathrm{~d}$ of the dry period. Panel A: Content of cis-9 18:1. The SEM ranged from 1.02 to 2.13\%. Panel B: Content of trans-18:1. The SEM ranged from 0.10 to $0.26 \%$. Panel C: Content of 18:2. The SEM ranged from 0.60 to $1.52 \%$.

of trans-18:1 at $d$ than other groups (Figure 5B). Abomasal infusion of soybean oil resulted in lower contents of cis-9 18:1 (Figure 5A) but markedly higher contents of 18:2 in hepatic PL (Figure 5C) at d 1 postpartum. Furthermore, contents of 20:3 (Figure 6A), 20:4 (Figure 6B), 22:6 (Figure 6C), and 24:0 (Figure 6D) were lowest at $\mathrm{d} 1$ in PL fractions from the liver of cows in group U. Linoleic acid can be desaturated and elongated to 20:3n- 6 and subsequently to 20:4, and $\alpha$-linolenic acid (18:3n-3) can be desaturated and elongated to form $20: 5$ and 22:6. Therefore, contents of 20:3, 20:4, 20:5, 22:5,
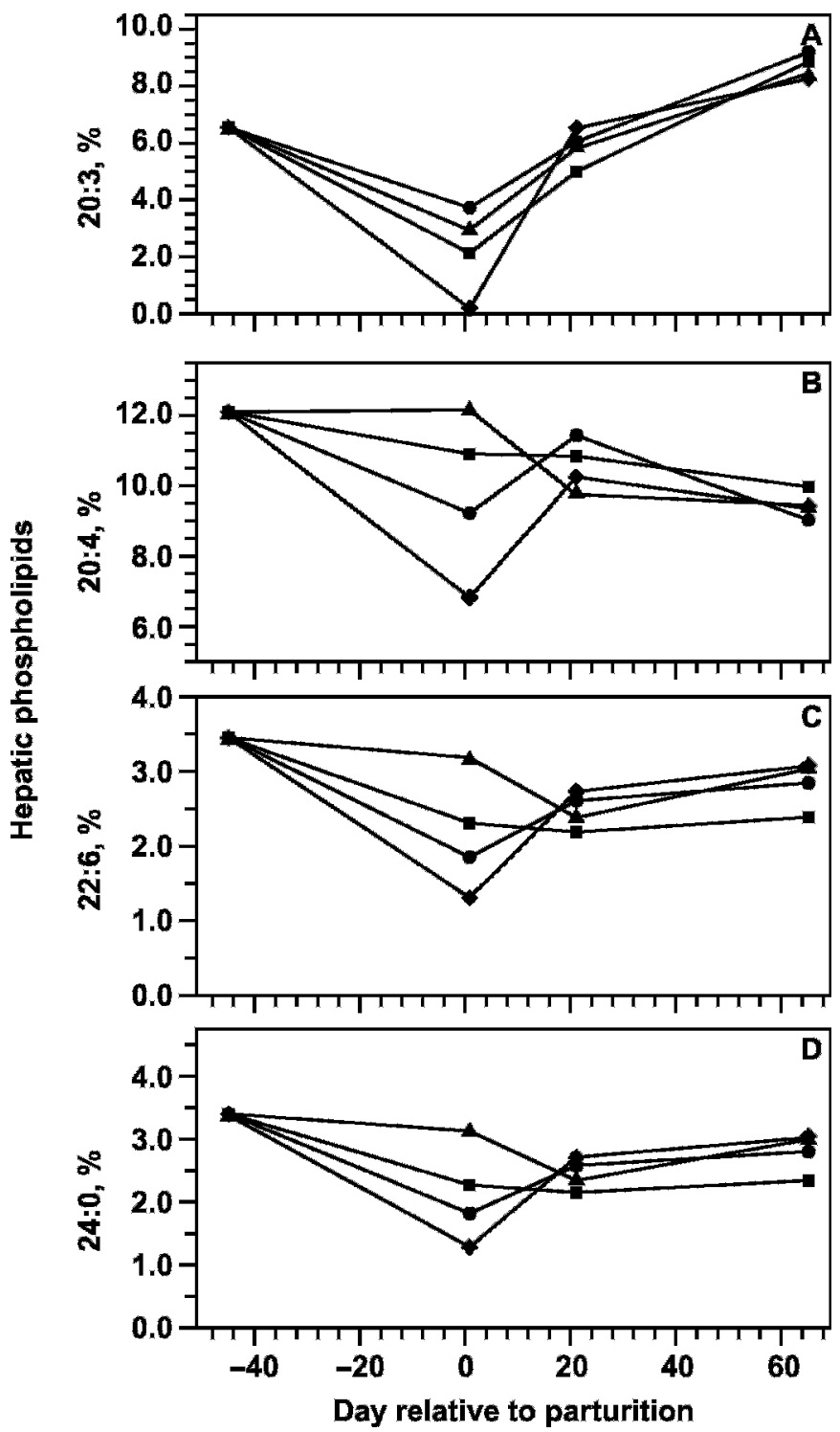

Figure 6. Treatment $\times$ day interactions $(P<0.05)$ for relative contents of long-chain fatty acids with $\geq 20$ carbons in phospholipids of liver for cows fed a control diet to meet $120 \%(\mathrm{CA}$; ) or $80 \%(\mathrm{CR}$; 口) of $\mathrm{NE}_{\mathrm{L}}$ requirements, a diet containing supplemental saturated long-chain FFA (S; $\boldsymbol{\Delta})$, or a diet supplemented with abomasal infusion of soybean oil (U; ) during the last $40 \mathrm{~d}$ of the dry period. Panel A: Content of 20:3. The SEM ranged from 0.60 to $1.42 \%$. Panel B: Content of 20:4. The SEM ranged from 0.53 to $1.40 \%$. Panel C: Content of $22: 6$. The SEM ranged from 0.26 to $0.65 \%$. Panel D: Content of 24:0. The SEM ranged from 0.18 to $0.42 \%$.

and 22:6 might be expected to be increased in hepatic PL at calving because tissue contents of $18: 2$ and 18:3 were increased. However, the greatly increased supply of 18:2 likely resulted in competition and displacement of other long-chain PUFA. Increasing the tissue contents of 18:2 also may have inhibited elongation and desaturation of 18:2 and 18:3 as observed in calves 
Table 10. Least squares means by day relative to parturition for weight percentages of fatty acids detected in phospholipid fractions of liver tissue

\begin{tabular}{|c|c|c|c|c|c|c|}
\hline \multirow{2}{*}{$\begin{array}{l}\text { Fatty acid, } \\
\%\end{array}$} & \multicolumn{4}{|c|}{ Day relative to calving } & \multirow{2}{*}{$\begin{array}{c}\text { Largest } \\
\text { SEM }\end{array}$} & \multirow[b]{2}{*}{$P$} \\
\hline & $-45^{1}$ & 1 & 21 & 65 & & \\
\hline $16: 0$ & 13.08 & $15.27^{\mathrm{a}}$ & $14.42^{\mathrm{a}}$ & $10.95^{\mathrm{b}}$ & 0.73 & 0.0001 \\
\hline $16: 1$ & 0.76 & $0.93^{\mathrm{ab}}$ & $1.36^{\mathrm{a}}$ & $0.76^{\mathrm{b}}$ & 0.19 & 0.05 \\
\hline $18: 0$ & 32.76 & $30.25^{\mathrm{b}}$ & $30.64^{\mathrm{b}}$ & $34.47^{\mathrm{a}}$ & 0.89 & 0.001 \\
\hline Cis-18:1 & 15.62 & $19.34^{\mathrm{a}}$ & $19.99^{\mathrm{a}}$ & $15.84^{\mathrm{b}}$ & 0.78 & 0.0001 \\
\hline Trans-18:1 & 0.78 & $0.74^{\mathrm{a}}$ & $0.57^{\mathrm{a}}$ & $0.19^{\mathrm{b}}$ & 0.09 & 0.0001 \\
\hline $18: 2$ & 9.90 & $16.49^{\mathrm{a}}$ & $10.83^{\mathrm{b}}$ & $11.13^{\mathrm{b}}$ & 0.52 & 0.0001 \\
\hline $18: 3$ & 0.08 & 0.18 & 0.07 & 0.10 & 0.04 & 0.16 \\
\hline 20.0 & 0.44 & $0.60^{\mathrm{a}}$ & $0.27^{\mathrm{b}}$ & $0.25^{\mathrm{b}}$ & 0.07 & 0.001 \\
\hline $20: 1$ & 0.01 & $0.00^{\mathrm{b}}$ & $0.01^{\mathrm{b}}$ & $0.25^{\mathrm{a}}$ & 0.06 & 0.01 \\
\hline $20: 2$ & 0.01 & $0.35^{\mathrm{ab}}$ & $0.07^{\mathrm{b}}$ & $0.51^{\mathrm{a}}$ & 0.19 & 0.01 \\
\hline $20: 3$ & 6.75 & $2.09^{c}$ & $5.98^{\mathrm{b}}$ & $9.18^{\mathrm{a}}$ & 0.50 & 0.0001 \\
\hline $20: 4$ & 12.58 & $10.08^{\mathrm{ab}}$ & $10.97^{\mathrm{a}}$ & $10.03^{\mathrm{b}}$ & 0.48 & 0.05 \\
\hline $20: 5$ & 0.39 & $0.06^{\mathrm{c}}$ & $0.38^{\mathrm{b}}$ & $0.67^{\mathrm{a}}$ & 0.10 & 0.0001 \\
\hline $22: 0$ & Trace $^{2}$ & $\mathrm{ND}^{3}$ & Trace & Trace & - & - \\
\hline $22: 5$ & 2.17 & 0.49 & 0.75 & 1.50 & 0.40 & 0.10 \\
\hline $22: 6$ & 3.54 & $2.20^{\mathrm{b}}$ & $2.54^{\mathrm{ab}}$ & $2.98^{\mathrm{a}}$ & 0.23 & 0.02 \\
\hline $24: 0$ & 0.68 & $0.58^{\mathrm{b}}$ & $0.88^{\mathrm{ab}}$ & $1.05^{\mathrm{a}}$ & 0.15 & 0.05 \\
\hline $26: 0$ & 0.44 & 0.34 & 0.27 & 0.16 & 0.11 & 0.37 \\
\hline
\end{tabular}

${ }^{\mathrm{a}-\mathrm{c}}$ Where overall effect of day was significant $(P<0.05)$, means without a common superscript letter are different $(P<0.05)$.

${ }^{1}$ Mean of pretreatment values used as covariate in statistical analysis.

${ }^{2}$ Trace amounts $(<0.05 \%)$ were detected in samples.

${ }^{3}$ Not detected in samples.

(Jenkins, 1988) and in incubations of ruminant tissues (Kaduce et al., 1982; Elattar and Lin, 1989).

To our knowledge, we provide the first report of LCFA profiles in hepatic PL of dairy cows during the periparturient period (Table 10). The overall changes are consistent with the effects of increased abundance of $\mathrm{C}_{16}$ and $\mathrm{C}_{18}$ LCFA from mobilization of adipose tissue TG during the peripartal period (Rukkwamsuk et al., 2000). Regardless of the dry period diet, proportions of 16:0, cis-9 18:1, trans-18:1, 18:2, and 20:0 were increased, whereas those of 20:3, 20:5, 22:5, 22:6, and 24:0 were decreased in PL fractions at calving; these LCFA then increased or decreased, respectively, by d 65 relative to proportions observed at $d 1$. General decreases in the percentages of LCFA $\geq 20$ carbons likely resulted from dilution or competition from the more abundant LCFA taken up from adipose tissue.

Potential implications of the extremely low content of $20: 5$ at d 1 are of interest. Replacement of highly unsaturated PUFA by saturated and monounsaturated LCFA from adipose tissue could limit availability of PUFA such as 20:5 for their unique functions. The limitations in essential PUFA supply for ruminants have been discussed previously (Noble, 1984). Preserved forages and confinement feeding limit intakes of 18:3, from which 20:5 is synthesized, and increase the relative availability of 18:2 and its products relative to cows in grazing situations.
To evaluate the potential impact of alterations in LCFA profiles of PL on membrane fluidity, we converted the weight percentages of LCFA to molar percentages and calculated the unsaturation index (Table 11) according to Luo et al. (1996). The index is based on the principle that an increasing number of double bonds in PUFA increases the fluidity effects in membranes, both because of the flexibility and rotational characteristics of highly unsaturated PUFA and because highly unsaturated PUFA such as 22:6 decrease the cholesterol contents of cell membranes (Hashimoto et al., 1999; Switzer et al., 2004). In other cell types, such as aortic endothelial cells, the unsaturation index was correlated strongly with fluorescence-based determinations of membrane fluidity (Hashimoto et al., 1999). In turn, an altered unsaturation index and membrane fluidity may affect cell function. For example, glucose transport into adipocytes from insulin-resistant rats increased linearly as the adipocyte membrane unsaturation index increased (Luo et al., 1996).

The unsaturation index of hepatic PL was lower at $\mathrm{d} 1$ than at either $\mathrm{d}-45$ or $\mathrm{d} 65$ (Table 11 ). Paradoxically, the unsaturation index at $d 1$ was highest for cows fed $\mathrm{S}$ and lowest for cows administered U. Although the PL content of 18:2 was markedly increased for cows fed $\mathrm{U}$, the greater unsaturation index for $\mathrm{S}$ was driven by the much greater contents of the highly unsaturated 20:3, 20:4, and 22:6 for $\mathrm{S}$ than for $\mathrm{U}$, as well as the 
Table 11. Least squares means by dietary treatment for molar percentages of fatty acids detected in phospholipid fractions of liver tissue biopsied at $\mathrm{d} 1$ relative to calving ${ }^{1}$

\begin{tabular}{|c|c|c|c|c|c|c|c|}
\hline \multirow{2}{*}{$\begin{array}{l}\text { Fatty acid, } \\
\mathrm{mol} / 100 \mathrm{~mol}\end{array}$} & \multirow[b]{2}{*}{$d-45^{2}$} & \multicolumn{4}{|c|}{ Dry period $\operatorname{diet}^{3}$} & \multirow{2}{*}{$\begin{array}{l}\text { Largest } \\
\text { SEM }\end{array}$} & \multirow[b]{2}{*}{ d $65^{4}$} \\
\hline & & $\mathrm{CA}$ & $\mathrm{CR}$ & $\mathrm{S}$ & $\mathrm{U}$ & & \\
\hline $16: 0$ & 11.72 & 14.61 & 13.94 & 13.17 & 13.79 & 1.60 & 9.81 \\
\hline $16: 1$ & 0.68 & 1.56 & 0.80 & 0.72 & 0.33 & 0.38 & 0.67 \\
\hline 18:0 & 32.41 & 29.03 & 30.91 & 29.08 & 32.28 & 1.87 & 34.08 \\
\hline Cis-18:1 & 15.35 & $23.79^{\mathrm{a}}$ & $19.52^{\mathrm{b}}$ & $18.27^{\mathrm{bc}}$ & $14.59^{\mathrm{c}}$ & 1.71 & 15.55 \\
\hline Trans-18:1 & 0.77 & 0.93 & 0.70 & 0.37 & 0.96 & 0.19 & 0.19 \\
\hline $18: 2$ & 9.66 & $11.14^{\mathrm{c}}$ & $14.45^{\mathrm{b}}$ & $12.80^{\mathrm{bc}}$ & $26.66^{\mathrm{a}}$ & 1.07 & 10.86 \\
\hline $18: 3$ & 0.08 & 0.19 & 0.10 & 0.39 & 0.02 & 0.09 & 0.09 \\
\hline 20.0 & 0.48 & 0.42 & 0.64 & 0.56 & 0.98 & 0.16 & 0.27 \\
\hline $20: 1$ & 0.01 & 0.00 & 0.00 & 0.00 & 0.00 & 0.01 & 0.26 \\
\hline $20: 2$ & 0.01 & 0.00 & 0.01 & 1.35 & 0.08 & 0.42 & 0.55 \\
\hline $20: 3$ & 7.17 & $4.13^{\mathrm{a}}$ & $2.37^{\mathrm{ab}}$ & $4.30^{\mathrm{a}}$ & $0.18^{\mathrm{b}}$ & 1.18 & 9.74 \\
\hline $20: 4$ & 13.29 & $10.35^{\mathrm{b}}$ & $12.19^{\mathrm{ab}}$ & $13.19^{\mathrm{a}}$ & $7.42^{\mathrm{c}}$ & 1.09 & 10.58 \\
\hline $20: 5$ & 0.41 & 0.01 & 0.18 & 0.05 & 0.02 & 0.22 & 0.70 \\
\hline $22: 0$ & 0.00 & 0.00 & 0.00 & 0.00 & 0.00 & 0.00 & 0.00 \\
\hline $22: 5$ & 2.48 & 0.01 & 0.69 & 0.96 & 0.84 & 0.98 & 1.72 \\
\hline $22: 6$ & 4.02 & $2.21^{\mathrm{b}}$ & $2.73^{\mathrm{ab}}$ & $3.68^{\mathrm{a}}$ & $1.50^{\mathrm{b}}$ & 0.55 & 3.38 \\
\hline $24: 0$ & 0.86 & $1.27^{\mathrm{a}}$ & $0.42^{\mathrm{ab}}$ & $1.21^{\mathrm{a}}$ & $0.09^{b}$ & 0.40 & 1.33 \\
\hline $26: 0$ & 0.60 & 0.28 & 0.35 & 1.01 & 0.25 & 0.30 & 0.22 \\
\hline Unsaturation index ${ }^{5}$ & 150 & $116^{\mathrm{b}}$ & $127^{\mathrm{ab}}$ & $138^{\mathrm{a}}$ & $113^{\mathrm{b}}$ & 7 & 144 \\
\hline
\end{tabular}

${ }^{\mathrm{a}-\mathrm{c}}$ Where the overall treatment $\times$ day interaction was significant $(P<0.05)$, means by treatment at $\mathrm{d} 1$ without a common superscript letter differ $(P<0.05)$.

${ }^{1}$ The effect of day was significant $(P<0.05)$ for all variables except 18:3, 22:0, $22: 5(P=0.10)$, and 26:0.

${ }^{2}$ Mean of pretreatment values used as covariate in statistical analysis.

${ }^{3}$ Control diet containing no supplemental fat fed to meet $120 \%(\mathrm{CA})$ or $80 \%(\mathrm{CR})$ of the $\mathrm{NE}_{\mathrm{L}}$ requirement for dry cows (NRC, 1989); $\mathrm{S}=$ diet containing mostly saturated fatty acids and fed to meet $120 \%$ of the $\mathrm{NE}_{\mathrm{L}}$ requirement; $\mathrm{U}=$ diet supplemented with soybean oil that was infused directly into the abomasum and fed to meet $120 \%$ of the $\mathrm{NE}_{\mathrm{L}}$ requirement.

${ }^{4}$ Least squares mean for effect of day across treatments, shown for comparison.

${ }^{5}$ Unsaturation index $=$ average number of double bonds per 100 fatty acid residues (Luo et al., 1996).

greater contents of cis-18:1, 18:3, and 20:2. Such changes in membrane fluidity could alter the activity or efficacy of cell receptors or other cell membrane integral proteins (Hauser and Phillips, 1979) by exerting conformational changes in their transmembrane domains (Kolodziej and Zammit, 1990a; Zammit et al., 1998). In rats, experimentally increased fluidity of mitochondrial membranes resulted in decreased sensitivity of carnitine palmitoyltransferase- 1 to malonyl-coenzyme A inhibition (Kolodziej and Zammit, 1990b); reducing membrane fluidity by decreasing the assay temperature restored sensitivity of carnitine palmitoyltransferase- 1 to inhibition by malonyl-coenzyme A. Although not evaluated specifically in our experiment, perhaps analogous effects of the lower unsaturation index on carnitine palmitoyltransferase activity at least partly explain the lower BHBA concentrations for cows given $\mathrm{U}$.

\section{LCFA in Hepatic TG}

Changes of LCFA in hepatic TG as a function of dry period treatments are shown in Table 12. Cows fed CA had greater 16:0 and 16:1 in hepatic TG than cows fed supplemental fats; $16: 0$ also tended $(P=0.14)$ to be greater for CA than for cows fed CR. These changes likely represent the greater availability of 18-carbon LCFA from the diet (S, U) or body lipid reserves (CR) that diluted or competed with 16-carbon LCFA. Cows receiving $\mathrm{U}$ had greater 18:2 in liver TG; similar to PL, the interaction of treatment $x$ day demonstrated that the increase was confined to $d 1$ postpartum (data not shown). Consequently, changes at d 1 postpartum as a result of dry period nutritional manipulations began to be reversed once the treatments were stopped at parturition.

The changes in composition of TG and PL from liver could be driven by the alterations in LCFA composition of adipose tissue as well as the direct incorporation from dietary-derived blood lipids. As discussed for adipose tissue, abomasal soybean oil infusion during the dry period in group $\mathrm{U}$ increased 18:2 in adipose tissue biopsied at $\mathrm{d} 1$ postpartum. Increases in plasma NEFA during the last $3 \mathrm{wk}$ before parturition (Figure 1A) indicated that cows on all treatments began to increase mobilization of adipose tissue TG before parturition. Consequently, peripartal mobilization of adipose tissue TG containing larger percentages of 18:2 in cows administered treatment $\mathrm{U}$ might have contributed to the in- 
Table 12. Least squares means by dietary treatment for weight percentages of fatty acids detected in the triacylglycerol fraction from liver tissue at 1,21 , and $65 \mathrm{~d}$ relative to calving

\begin{tabular}{|c|c|c|c|c|c|c|c|c|c|}
\hline \multirow{3}{*}{$\begin{array}{l}\text { Fatty acid, } \\
\%\end{array}$} & \multirow{2}{*}{\multicolumn{4}{|c|}{ Dry period diet ${ }^{1}$}} & \multirow{3}{*}{$\begin{array}{l}\text { Largest } \\
\text { SEM }\end{array}$} & \multicolumn{3}{|c|}{ Contrast, $P$} & \multirow{3}{*}{$\begin{array}{c}\text { Trt } \times \\
\text { day }\end{array}$} \\
\hline & & & & & & & $\mathrm{S}+\mathrm{U}$ & CA vs. & \\
\hline & $\mathrm{CA}$ & $\mathrm{CR}$ & $\mathrm{S}$ & $\mathrm{U}$ & & S vs. U & vs. CA & CR & \\
\hline $16: 0$ & 39.19 & 35.20 & 34.60 & 32.34 & 2.36 & 0.27 & 0.05 & 0.14 & 0.93 \\
\hline $16: 1$ & 4.00 & 2.91 & 2.33 & 2.33 & 0.51 & 0.90 & 0.02 & 0.13 & 0.15 \\
\hline 18:0 & 14.18 & 15.88 & 16.32 & 17.13 & 2.20 & 0.96 & 0.47 & 0.67 & 0.79 \\
\hline Cis-18:1 & 25.05 & 24.86 & 23.51 & 19.17 & 2.17 & 0.15 & 0.16 & 0.77 & 0.84 \\
\hline Trans-18:1 & 0.69 & 0.85 & 0.44 & 0.41 & 0.22 & 0.88 & 0.36 & 0.66 & 0.89 \\
\hline $18: 2$ & 6.36 & 7.61 & 7.50 & 13.72 & 1.01 & 0.001 & 0.01 & 0.44 & 0.001 \\
\hline $18: 3$ & 0.15 & 0.21 & 0.20 & 0.57 & 0.15 & 0.04 & 0.28 & 0.77 & 0.53 \\
\hline 20.0 & 0.15 & 0.28 & 0.47 & 0.50 & 0.15 & 0.94 & 0.11 & 0.55 & 0.74 \\
\hline $20: 1$ & Trace $^{2}$ & $\mathrm{ND}^{3}$ & 0.26 & ND & 0.12 & 0.13 & 0.58 & 0.83 & 0.21 \\
\hline $20: 3$ & 2.64 & 2.84 & 3.08 & 3.37 & 0.60 & 0.84 & 0.52 & 0.89 & 0.99 \\
\hline $20: 4$ & 2.61 & 2.71 & 3.02 & 2.59 & 0.59 & 0.59 & 0.86 & 0.97 & 0.98 \\
\hline $20: 5$ & 0.84 & 1.28 & 1.60 & 1.65 & 0.37 & 0.98 & 0.12 & 0.42 & 0.62 \\
\hline $22: 0$ & 0.39 & 0.22 & 0.66 & 0.18 & 0.30 & 0.19 & 0.98 & 0.64 & 0.38 \\
\hline $22: 1$ & ND & ND & ND & Trace & - & - & - & - & - \\
\hline $22: 5$ & 0.93 & 1.95 & 1.81 & 2.00 & 1.41 & 0.91 & 0.27 & 0.30 & 0.87 \\
\hline $22: 6$ & 0.16 & 0.13 & 0.19 & 0.35 & 0.25 & 0.62 & 0.73 & 0.92 & 0.62 \\
\hline $24: 0$ & 0.96 & 1.48 & 1.80 & 1.43 & 0.52 & 0.58 & 0.37 & 0.52 & 0.80 \\
\hline $24: 1$ & 0.19 & 0.09 & ND & 0.30 & 0.16 & 0.12 & 0.83 & 0.67 & 0.35 \\
\hline $26: 0$ & 1.52 & 1.49 & 2.19 & 1.97 & 0.41 & 0.69 & 0.35 & 0.91 & 0.63 \\
\hline
\end{tabular}

${ }^{1}$ Control diet containing no supplemental fat fed to meet $120 \%(\mathrm{CA})$ or $80 \%(\mathrm{CR})$ of the $\mathrm{NE}_{\mathrm{L}}$ requirement for dry cows (NRC, 1989); $\mathrm{S}=$ diet containing mostly saturated fatty acids and fed to meet $120 \%$ of the $\mathrm{NE}_{\mathrm{L}}$ requirement; $\mathrm{U}=$ diet supplemented with soybean oil that was infused directly into the abomasum and fed to meet $120 \%$ of the $\mathrm{NE}_{\mathrm{L}}$ requirement.

${ }^{2}$ Trace amounts $(<0.05 \%)$ were detected in the samples.

${ }^{3}$ Not detected in samples.

creased 18:2 in liver TG and PL at d 1 postpartum. However, dietary LCFA can enter the liver by processes other than by uptake of NEFA mobilized from adipose tissue (Drackley, 1999). Dietary PUFA are delivered to tissues both in NEFA form and via low- and high-density lipoproteins (Drackley, 2005). Therefore, given the large amount of PUFA infused, abomasal infusion of soybean oil likely had a much greater direct influence on LCFA composition of liver tissue fractions than did enrichment in adipose TG and its subsequent mobilization.

The LCFA composition of TG in liver is presented in Table 13 by day relative to parturition. In general, alterations of liver TG composition largely reflected the influence of NEFA mobilized from adipose tissue, as observed by Rukkwamsuk et al. (2000). Proportions of 16:0, 16:1, cis-18:1, trans-18:1, 18:2, 18:3, and 20:0 were increased, whereas those of 18:0, 20:3, 20:4, 20:5, 22:0, 24:0, and 26:0 were decreased in TG fractions at $d 1$ after calving. Changes generally began to be reversed by d 21 postpartum for some LCFA and were similar to $d-45$ values by $d 65$. The decreased percentages of 18:0 at $\mathrm{d} 1$ and 21 reflect the observation that 18:0 seems to be taken up by liver at a very low rate relative to other LCFA mobilized from adipose tissue (Rukkwamsuk et al., 2000; Mashek and Grummer, 2003b); therefore, its content in liver TG is diluted as other, more abundant LCFA (16:0, cis-18:1) are taken up and esterified.

\section{Correlations Between Hepatic LCFA and Hepatic Total Lipid Content}

The relationship between altered hepatic tissue LCFA composition and peripartal hepatic lipid content was examined further by correlating the percentages of LCFA detected in PL and TG fractions with the content of total lipids in liver tissue biopsied at $\mathrm{d} 1$ postpartum. The content of 20:4 in TG was significantly inversely correlated $(\mathrm{r}=-0.59 ; P<0.05)$ with the total lipid content in liver tissue. Correlation coefficients of $-0.49(P=0.09)$ and $-0.46(P=0.11)$ also indicated tendencies for inverse relationships between total liver lipids and 16:1 and 20:5, respectively, in the TG fraction. The content of 22:6 in PL tended to be inversely correlated with the total lipid content in liver $(r=-0.48$, $P=0.09$ ); no other correlation coefficients approached significance. Given the small sample size, it is important that these relationships be interpreted with caution. Nevertheless, the inverse relationships between total lipid concentration in liver and the highly unsaturated PUFA in hepatic PL and TG warrant further investigation. 
Table 13. Least squares means by day relative to parturition for weights of fatty acids detected in triacylglycerol fractions of liver tissue

\begin{tabular}{|c|c|c|c|c|c|c|}
\hline \multirow{2}{*}{$\begin{array}{l}\text { Fatty acid, } \\
\%\end{array}$} & \multicolumn{4}{|c|}{ Day relative to calving } & \multirow{2}{*}{$\begin{array}{c}\text { Largest } \\
\text { SEM }\end{array}$} & \multirow[b]{2}{*}{$P$} \\
\hline & $-45^{1}$ & 1 & 21 & 65 & & \\
\hline $16: 0$ & 26.75 & $42.28^{\mathrm{a}}$ & $38.98^{\mathrm{a}}$ & $26.04^{b}$ & 1.85 & 0.0001 \\
\hline $16: 1$ & 1.80 & $3.61^{\mathrm{a}}$ & $3.45^{\mathrm{a}}$ & $1.74^{\mathrm{b}}$ & 0.38 & 0.0001 \\
\hline $18: 0$ & 25.46 & $10.62^{\mathrm{b}}$ & $12.25^{\mathrm{b}}$ & $24.72^{\mathrm{a}}$ & 1.43 & 0.0001 \\
\hline Cis-18:1 & 23.89 & $26.61^{\mathrm{a}}$ & $26.60^{\mathrm{a}}$ & $17.17^{\mathrm{b}}$ & 1.73 & 0.0001 \\
\hline Trans-18:1 & 0.72 & $0.76^{\mathrm{a}}$ & $0.83^{\mathrm{a}}$ & $0.24^{\mathrm{b}}$ & 0.19 & 0.02 \\
\hline $18: 2$ & 6.07 & $9.58^{\mathrm{a}}$ & $7.38^{\mathrm{b}}$ & $9.42^{\mathrm{a}}$ & 0.87 & 0.02 \\
\hline $18: 3$ & 0.23 & $0.58^{\mathrm{a}}$ & $0.23^{\mathrm{b}}$ & $0.05^{\mathrm{b}}$ & 0.12 & 0.01 \\
\hline 20.0 & 0.46 & $0.62^{\mathrm{a}}$ & $0.33^{\mathrm{ab}}$ & $0.10^{b}$ & 0.13 & 0.02 \\
\hline $20: 1$ & 0.06 & 0.06 & 0.09 & 0.07 & 0.06 & 0.23 \\
\hline $20: 3$ & 2.36 & $0.77^{\mathrm{c}}$ & $1.96^{\mathrm{b}}$ & $6.17^{\mathrm{a}}$ & 0.46 & 0.0001 \\
\hline $20: 4$ & 2.58 & $1.39^{\mathrm{b}}$ & $2.13^{\mathrm{b}}$ & $4.67^{\mathrm{a}}$ & 0.39 & 0.0001 \\
\hline $20: 5$ & 0.98 & $0.35^{\mathrm{b}}$ & $0.90^{\mathrm{b}}$ & $2.75^{\mathrm{a}}$ & 0.31 & 0.0001 \\
\hline $22: 0$ & 0.26 & $0.15^{\mathrm{b}}$ & $0.15^{\mathrm{b}}$ & $0.80^{\mathrm{a}}$ & 0.24 & 0.02 \\
\hline $22: 1$ & $\mathrm{ND}^{2}$ & ND & ND & Trace $^{3}$ & - & - \\
\hline $22: 5$ & 4.68 & 1.32 & 2.09 & 1.63 & 0.50 & 0.63 \\
\hline $22: 6$ & 0.35 & 0.14 & 0.21 & 0.28 & 0.22 & 0.84 \\
\hline $24: 0$ & 1.31 & $0.48^{\mathrm{b}}$ & $1.06^{\mathrm{a}}$ & $0.45^{\mathrm{b}}$ & 0.38 & 0.0001 \\
\hline $24: 1$ & 0.11 & Trace & 0.10 & 0.33 & 0.14 & 0.16 \\
\hline $26: 0$ & 1.94 & $0.68^{b}$ & $1.30^{\mathrm{b}}$ & $3.38^{\mathrm{a}}$ & 0.33 & 0.0001 \\
\hline
\end{tabular}

${ }^{\mathrm{a}-\mathrm{c}}$ Where overall effect of day was significant $(P<0.05)$, means without a common superscript letter are different $(P<0.05)$.

${ }^{1}$ Mean of pretreatment values used as covariate in statistical analysis.

${ }^{2}$ Not detected in the samples.

${ }^{3}$ Trace amounts $(<0.05 \%)$ were detected in samples.

\section{CONCLUSIONS}

Our research demonstrates that it is feasible to alter LCFA profiles of plasma lipids, adipose tissue, and PL and TG of liver via relatively short periods of nutritional manipulation during the dry period. Moderate feed restriction during the dry period caused only modest changes in the LCFA profiles of hepatic PL and TG; therefore, beneficial effects of dry period feed restriction (Douglas et al., 2006) seem unlikely to be a result of altered hepatic LCFA composition. Provision of soybean oil to the postruminal digestive tract during the last 40 $\mathrm{d}$ of the dry period resulted in marked increases in $\mathrm{C}_{18}$ polyenoic LCFA in plasma and adipose tissue, and in TG and PL fractions from liver tissue at $\mathrm{d} 1$ after calving. Profiles of LCFA in tissues were changed during the peripartal period in dairy cows regardless of dry period dietary treatments as a result of adipose TG mobilization. The content of n-3 PUFA in hepatic PL decreased around calving; the implications of such changes are unknown but warrant additional investigation. Changes in the LCFA profile of hepatic PL and TG were mostly reversed by $21 \mathrm{~d}$ after calving. Dietary fat or oil infusion directly into the abomasum did not increase peripartal hepatic lipid accumulation. Abomasal oil infusion prepartum decreased BHBA in plasma during the early postpartal period despite similar NEFA concentrations, which might be due to altered hepatic metabolism of LCFA resulting from changes in the hepatic LCFA profile. Dietary manipulation of tissue LCFA composition during the dry period is feasible and has the potential to positively affect the metabolic adaptation to lactation.

\section{ACKNOWLEDGMENTS}

The authors are grateful to Milk Specialties Co. (Dundee, IL) for donating the Energy Booster 100 used in this experiment, and to Archer Daniels Midland Co. (Decatur, IL) for donating the soybean hulls.

\section{REFERENCES}

Andersen, J. B., A. S. Hansen, N. B. Litherland, M. O. Nielsen, J. K. Drackley, and K. L. Ingvartsen. 2003. Effects of polyunsaturated $\omega-3$ fatty acids on short time regulation of hepatic fat metabolism in liver tissue from dairy cows. Acta Vet. Scand. 98(Suppl.):317-318.

AOAC. 1995. Official Methods of Analysis. 16th ed. Association of Official Analytical Chemists, Arlington, VA.

Ashes, J. R., E. Fleck, and T. W. Scott. 1995. Dietary manipulation of membrane lipids and its implications for their role in the production of second messengers. Pages 373-386 in Ruminant Physiology: Digestion, Metabolism, Growth, and Reproduction. Proc. Eighth International Symp. Rumin. Physiol. Ferdinand Ende Verlag, Stuttgart, Germany.

Bateman, H. G., and T. C. Jenkins. 1997. A method for extraction and separation by solid phase extraction of neutral lipid, free fatty acids, and polar lipid from mixed microbial cultures. J. Sci. Food Agric. 45:132-134.

Beaulieu, A. D., J. K. Drackley, and N. R. Merchen. 2002. Concentrations of conjugated linoleic acid (cis-9, trans-11-octadecadienoic acid) are not increased in tissue lipids of cattle fed a high-concen- 
trate diet supplemented with soybean oil. J. Anim. Sci. 80:847861.

Benson, J. A., and C. K. Reynolds. 2001. Effects of abomasal infusion of long-chain fatty acids on splanchnic metabolism of pancreatic and gut hormones in lactating dairy cows. J. Dairy Sci. 84:1488-1500.

Bilby, T. R., T. Jenkins, C. R. Staples, and W. W. Thatcher. 2006. Pregnancy, bovine somatotropin, and dietary n-3 fatty acids in lactating dairy cows: III. Fatty acid distribution. J. Dairy Sci. 89:3386-3399.

Burhans, W. S., and A. W. Bell. 1998. Feeding the transition cow. Pages 247-257 in Proc. Cornell Nutr. Conf. Cornell Univ., Ithaca, NY.

Calder, P. C. 2005. Polyunsaturated fatty acids and inflammation. Biochem. Soc. Trans. 33:423-427.

Chilliard, Y., G. Gagliostro, J. Flèchet, J. Lefaivre, and I. Sebastian. 1991. Duodenal rapeseed oil infusion in early and midlactation cows. 5. Milk fatty acids and adipose tissue lipogenic activities. J. Dairy Sci. 74:1844-1854.

Christensen, R. A., J. K. Drackley, D. W. LaCount, and J. H. Clark. 1994. Infusion of four long-chain fatty acid mixtures into the abomasum of lactating dairy cows. J. Dairy Sci. 77:1052-1069.

Collins, R. A., and I. M. Reid. 1980. A correlated biochemical and stereological study of periparturient fatty liver in the dairy cow. Res. Vet. Sci. 28:373-376.

Cook, L. J., T. W. Scott, G. J. Faichney, and H. L. Davies. 1972. Fatty acid interrelationships in plasma, liver, muscle, and adipose tissues of cattle fed safflower oil protected from ruminal hydrogenation. Lipids 7:83-89.

Dann, H. M., and J. K. Drackley. 2005. Carnitine palmityoltransferase I in liver of periparturient dairy cows: Effects of prepartum intake, postpartum induction of ketosis, and periparturient disorders. J. Dairy Sci. 88:3851-3859.

Dann, H. M., D. E. Morin, M. R. Murphy, G. A. Bollero, and J. K. Drackley. 2005. Prepartum intake, postpartum induction of ketosis, and periparturient disorders affect the metabolic status of dairy cows. J. Dairy Sci. 88:3249-3264.

Delbecchi, L., C. E. Ahnadi, J. J. Kennelly, and P. Lacasse. 2001. Milk fatty acid composition and mammary lipid metabolism in Holstein cows fed protected or unprotected canola seeds. J. Dairy Sci. 84:1375-1381.

Douglas, G. N., T. R. Overton, H. G. Bateman, II, H. M. Dann, and J. K. Drackley. 2006. Prepartal plane of nutrition, regardless of dietary energy source, affects periparturient metabolism and dry matter intake in Holstein cows. J. Dairy Sci. 89:2141-2157.

Douglas, G. N., T. R. Overton, H. G. Bateman, II, and J. K. Drackley. 2004. Peripartal metabolism and production of Holstein cows fed diets supplemented with fat during the dry period. J. Dairy Sci. 87:4210-4220.

Drackley, J. K. 1999. Biology of dairy cows during the transition period: The final frontier? J. Dairy Sci. 82:2259-2273.

Drackley, J. K. 2005. Interorgan lipid and fatty acid metabolism in growing ruminants. Pages 323-350 in Biology of Metabolism in Growing Animals. D. G. Burrin and H. J. Mersmann, ed. Elsevier Limited, Edinburgh, UK.

Drackley, J. K., D. C. Beitz, M. J. Richard, and J. W. Young. 1992a. Metabolic changes in dairy cows with ketonemia in response to feed restriction and dietary 1,3-butanediol. J. Dairy Sci. 75:1622-1634.

Drackley, J. K., T. H. Klusmeyer, A. M. Trusk, and J. H. Clark. 1992b. Infusion of long-chain fatty acids varying in saturation and chain length into the abomasum of lactating dairy cows. J. Dairy Sci. 75:1517-1526.

Drackley, J. K., J. J. Veenhuizen, M. J. Richard, and J. W. Young. 1991. Metabolic changes in blood and liver of dairy cows during either feed restriction or administration of 1,3-butanediol. J. Dairy Sci. 74:4254-4264.

Elattar, T. M., and H. S. Lin. 1989. Comparison of the inhibitory effect of polyunsaturated fatty acids on prostaglandin synthesis in oral squamous carcinoma cells. Prostaglandins Leukot. Essent. Fatty Acids 38:119-125.
Gagliostro, G., and Y. Chilliard. 1991. Duodenal rapeseed oil infusion in early and midlactation cows. 2 . Voluntary intake, milk production, and composition. J. Dairy Sci. 74:499-509.

Hara, A., and N. S. Radin. 1978. Lipid extraction of tissues with a low-toxicity solvent. Anal. Biochem. 90:420-426.

Hashimoto, M., S. Hossain, H. Yamasaki, K. Yazawa, and S. Masumura. 1999. Effects of eicosapentaenoic acid and docosahexaenoic acid on plasma membrane fluidity of aortic endothelial cells. Lipids 34:1297-1304.

Hauser, H., and M. C. Phillips. 1979. Interaction of the polar groups of phospholipid bilayer membranes. Prog. Surf. Membr. Sci. 13:297-313.

Herdt, T. H., J. S. Liesman, B. J. Gerloff, and R. S. Emery. 1983. Reduction of serum triacylglycerol-rich lipoprotein concentrations in cows with hepatic lipidosis. Am. J. Vet. Res. 44:293-296.

Hulbert, A. J., N. Turner, L. H. Storlien, and P. L. Else. 2005. Dietary fats and membrane function: Implications for metabolism and disease. Biol. Rev. Camb. Philos. Soc. 80:155-169.

Jenkins, J. J. 1988. Factors affecting poor performance and scours in preruminant calves fed corn oil. J. Dairy Sci. 71:3013-3020.

Jenkins, K. J., G. Griffith, and J. K. G. Kramer. 1988. Plasma lipoproteins in neonatal, preruminant, and weaned calf. J. Dairy Sci. 71:3003-3012.

Jump, D. B. 2002. Dietary polyunsaturated fatty acids and regulation of gene transcription. Curr. Opin. Lipidol. 13:155-164.

Kaduce, T. L., A. A. Spector, and R. S. Bar. 1982. Linoleic acid metabolism and prostaglandin production by cultured bovine pulmonary artery endothelial cells. Arteriosclerosis 2:380-389.

Kolodziej, M. P., and V. A. Zammit. 1990a. Re-evaluation of the interaction of malonyl-CoA with the rat liver mitochondrial carnitine palmitoyltransferase system by using purified outer membranes. Biochem. J. 267:85-90.

Kolodziej, M. P., and V. A. Zammit. 1990b. Sensitivity of inhibition of rat liver mitochondrial outer-membrane carnitine palmitoyltransferase by malonyl-CoA to chemical- and temperature-induced changes in membrane fluidity. Biochem. J. 272:421-425.

Litherland, N. B., S. Thire, A. D. Beaulieu, C. K. Reynolds, J. A. Benson, and J. K. Drackley. 2005. Dry matter intake is decreased more by abomasal infusion of unsaturated free fatty acids than by unsaturated triglycerides. J. Dairy Sci. 88:632-643.

Littell, R. C., G. A. Milliken, W. W. Stroup, and R. D. Wolfinger. 1996. SAS System for Mixed Models. SAS Institute Inc., Cary, NC.

Lo, S., J. C. Russell, and A. W. Taylor. 1970. Determination of glycogen in small tissue samples. J. Appl. Physiol. 28:234-236.

Luo, J., S. W. Rizkalla, J. Boillot, C. Alamowitch, H. Chaib, F. Bruzzo, N. Desplanque, A.-M. Dalix, G. Durand, and G. Slama. 1996. Dietary (n-3) polyunsaturated fatty acids improve adipocyte insulin action and glucose metabolism in insulin-resistant rats: relation to membrane fatty acids. J. Nutr. 126:1951-1958.

Mashek, D. G., S. J. Bertics, and R. R. Grummer. 2002. Metabolic fate of long-chain unsaturated fatty acids and their effects on palmitic acid metabolism and gluconeogenesis in bovine hepatocytes. J. Dairy Sci. 85:2283-2289.

Mashek, D. G., S. J. Bertics, and R. R. Grummer. 2005. Effects of intravenous triacylglycerol emulsions on hepatic metabolism and blood metabolites in fasted dairy cows. J. Dairy Sci. 88:100-109.

Mashek, D. G., and R. R. Grummer. 2003a. Effect of long chain fatty acids on lipid and glucose metabolism in monlayer cultures of bovine hepatocytes. J. Dairy Sci. 86:2390-2396.

Mashek, D. G., and R. R. Grummer. 2003b. Short communication: Net uptake of nonesterified long chain fatty acids by the perfused caudate lobe of the caprine liver. J. Dairy Sci. 86:1218-1220.

NRC. 1989. Nutrient Requirements of Dairy Cattle. 6th rev. ed. National Academy Press, Washington, DC.

NRC. 2001. Nutrient Requirements of Dairy Cattle. 7th rev. ed. National Academy Press, Washington, DC.

Noble, R. C. 1984. Essential fatty acids in the ruminant. Pages 185200 in Fat in Animal Nutrition. J. Wiseman, ed. Butterworths, London, UK.

Rukkwamsuk, T., M. J. H. Geelen, T. A. M. Kruip, and T. Wensing. 2000. Interrelation of fatty acid composition in adipose tissue, 
serum, and liver of dairy cows during the development of fatty liver postpartum. J. Dairy Sci. 83:52-59.

Rukkwamsuk, T., T. A. M. Kruip, G. A. L. Meijer, and T. Wensing. 1999. Hepatic fatty acid composition in periparturient dairy cows with fatty liver induced by intake of a high energy diet in the dry period. J. Dairy Sci. 82:280-287.

Skaar, T. C., R. R. Grummer, M. R. Dentine, and R. H. Stauffacher. 1989. Seasonal effects of prepartum and postpartum fat and niacin feeding on lactation performance and lipid metabolism. J. Dairy Sci. 72:2028-2038.

Spector, A. A. 2000. Lipid metabolism: Essential fatty acids. Pages 365-383 in Biochemical and Physiological Aspects of Human Nutrition. M. H. Stipanuk, ed. W. B. Saunders Co., Philadelphia, PA.

Switzer, K. C., D. N. McMurray, and R. S. Chapkin. 2004. Effects of dietary n-3 polyunsaturated fatty acids on T-cell membrane function and function. Lipids 39:1163-1170.

Sukhija, P. S., and D. L. Palmquist. 1988. Rapid method for determination of total fatty acid content and composition of feedstuffs and feces. J. Agric. Food Chem. 36:1202-1206.
Van Soest, P. J., J. B. Robertson, and B. A. Lewis. 1991. Methods for dietary fiber, neutral detergent fiber, and nonstarch polysaccharides in relation to animal nutrition. J. Dairy Sci. 74:35833597.

Wildman, E. E., G. M. Jones, P. E. Wagner, R. L. Boman, H. F. Troutt, and T. N. Lesch. 1982. A dairy cow body condition scoring system and its relationship to selected production characteristics. J. Dairy Sci. 65:495-501.

Yoshida, H., M. Mawatari, I. Ikeda, K. Imaizumi, A. Seto, and H. Tsuji. 1999. Effect of dietary seal and fish oils on triacylglycerol metabolism in rats. J. Nutr. Sci. Vitaminol. (Tokyo) 45:411-421.

Zamaria, N. 2004. Alteration of polyunsaturated fatty acid status and metabolism in health and disease. Reprod. Nutr. Dev. 44:273-282.

Zammit, V. A., C. G. Corstorphine, M. P. Kolodziej, and F. Fraser. 1998. Lipid molecular order in liver mitochondrial outer membranes, and sensitivity of carnitine palmitoyltransferase I to malonyl-CoA. Lipids 33:371-376. 